\title{
Comparative analysis of energy impacts of traditional and partly electronic environmental auditing: learning from the Japanese automotive industry case
}

\author{
C MBOHWA ${ }^{1}$
}

\begin{abstract}
This paper does a comparative analysis and assessment of energy impacts of traditional and partly electronic ISO 14001 environmental management system auditing that using videoconferencing systems. The focus is on the Japanese automotive industry. The idea is to quantify the environmental impacts of auditing and resolve the important question on whether or not the use of information and communication technology (ICT) in environmental auditing reduces environmental impacts in ISO 14001 environmental management systems. The main results show that there are no clear energy savings or environmental advantages associated with ICT use in environmental auditing for the set system boundary. However electronic auditing is shown to have clear advantages for stated variables within the model, for example when the distance travelled by the auditors by train and by car is less than $75 \mathrm{~km}$ and $17 \mathrm{~km}$ per day respectively. A comparison of modes of travel by auditors, shows that rail travel offers the most environmental and energy benefits. It is also noted that travel dominates in terms of energy consumption and environmental burdens compared to all other environmental aspects associated with auditing. The study contributes to knowledge in that among other things, it enables researchers to draw parallels from it applicable to other industrial sectors and other countries. Southern African countries can use this methodology in analysing auditing methods with little or no changes in the model used.
\end{abstract}

Keywords: energy/environmental impacts, traditional/electronic environmental auditing

\section{Introduction}

This paper analyses the energy implications of traditional auditing of environmental management systems compared to an auditing system that incorporates electronic methods like use of e-mails, Internet and teleconferencing. The modelling process focuses on the

1 Dr. Charles Mbohwa is a Senior Lecturer in the Department of Quality and Operations Management at the University of Johannesburg. E-mail: cmbohwa@uj.ac.za. 
Japanese automotive industry where the plants and facilities conduct audits certify or confirm the compliance of ISO 14001 environmental management systems. Automobile manufacturers have a number of facilities and by analyzing all of them as this study did, a fuller picture of auditing issues in the industry in Japan could be discerned. The thinking is that use of information and communication technology (ICT) has the potential to reduce total transportation needs, paper use and the time needed to conduct an environmental audit by providing alternative ways to arrange meetings, eliminating or reducing commuter or business travel. The use of Internet for auditing documents and records ideally contributes through creation of paperless systems and dematerialization. Being able to study environmental documents while the external auditors are within their own normal environment can also reduce the time needed to complete an audit. These assumed gains have to be compared with the extra energy consumption as a result of increased use of ICT. It is not clear if this travel reduction and substitution with electronic media has net positive impacts on the environment. In this case electronic auditing of an ISO 14001 certified environmental management system in the Japanese automotive industry is compared with traditional auditing, to attempt a resolution of this problem.

\subsection{The need for environmental auditing}

The main idea of an environmental audit is to ensure that there is third part confirmation that a company's environmental management system meets the requirements of ISO 14001. This assures any interested parties about the effectiveness and prevalence of an environmental management system in the audited company. This, when accompanied with the use of appropriate environmental performance data, assures stakeholders that the company has in place an effective system that limits its environmental impacts. The specific requirement in the ISO 14001 standard is to "establish and maintain programmes and procedures for periodic environmental management system audits." (ISO 14001, 1996) This helps to determine conformance of the environmental management system to ISO 14001 requirements. The information collected during this process is useful, particularly when management reviews of the system are done. Activities and areas to be considered during the audit are clearly outlined and the audit programs and procedures are created by the organization in such a way that ensures impartiality and objectivity by both internal and external auditors. This is done at the beginning of certification and later on to reconfirm certification by the registering agent. Depending on the type of organization, this exercise can take up to a week. Figure 1 shows the role of environmental auditing within ISO 14001. (Callaghan, 1996)

\subsection{Transportation reduction and substitution}

Transportation is a major contributor to environmental pollution and 
environmental problems such as global warming, acidification, eutrophication and smog hence the need to reduce it. Transport substitution by use of teleconferencing (video and audio conferencing) can play an important role in the travel reduction. However the reality is that traffic in Japan has been and contributed $21.6 \%$ of total carbon dioxide $\left(\mathrm{CO}_{2}\right)$ emissions in 1998 , which amounted to 257 million tons out of a total of 1,188 million tons. (JAL, 2001) $55.5 \%$ of these emissions were from private cars. Japan's motor vehicles and railroads account for almost all passenger traffic. In the year 2000, 84.69 billion passengers were transported domestically, an increase of $0.8 \%$ from the previous year. The total number of passenger-kilometres was 1,419.69 billion out of which 384.44 billion were for railways and 951.25 billion for motor vehicles. (Statistical Handbook of Japan, 2002) On the other hand $\mathrm{CO}_{2}$ emissions in Japan in 1993, contributed to $94.4 \%$ of global warming potential. There is therefore a need for more effort to reduce traffic volume in Japan through reduction of travel.

\section{Figure 1: Environmental auditing within ISO 14001 (Source: Callaghan, 1996)}

\section{COMMITMENT}

INITIAL REVIEW
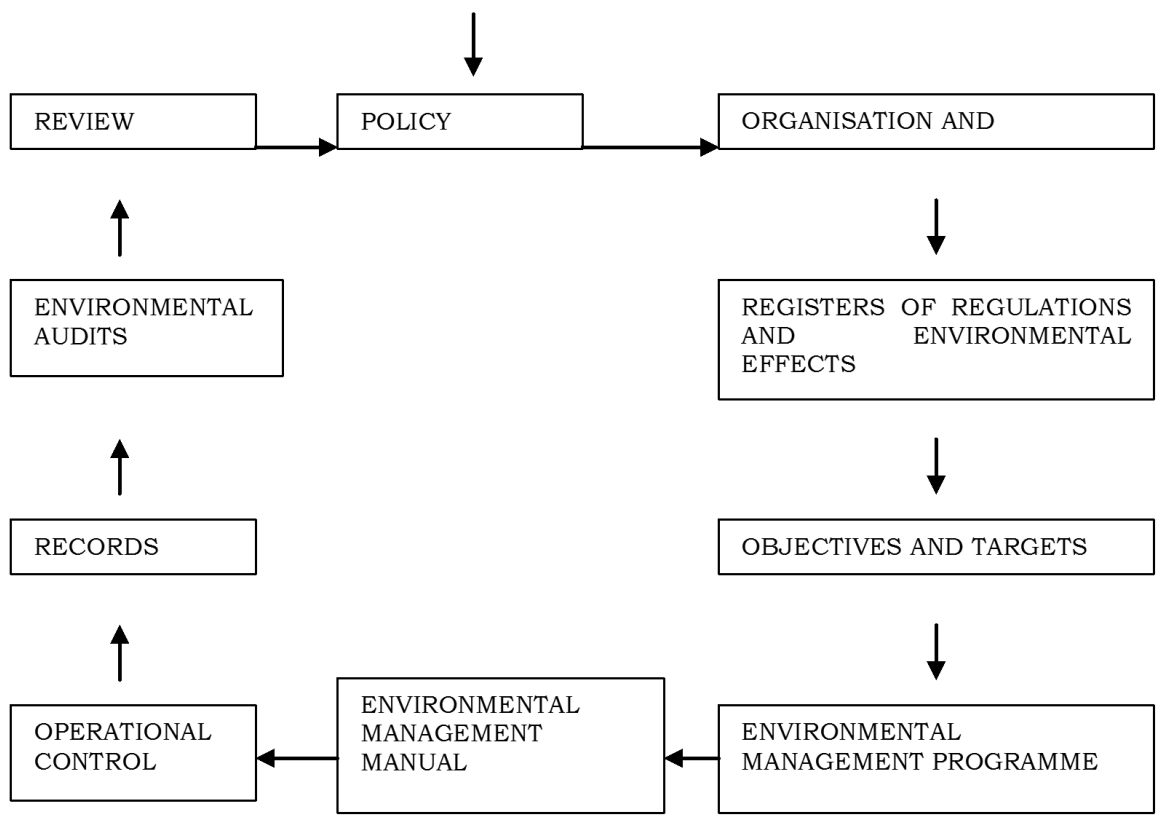


\subsection{The problem scope}

The traditional system of auditing for the automotive companies in Japan was assessed, targeting the certified plants and facilities within Japan. The subsidiaries outside Japan were not considered since they use local certification agencies and registrars. The electronic system was also considered for the same organizational units involving the use of Internet and e-mail to access the audited documents and records and video conferencing facilities to conduct interviews and meetings between the external auditors and the management/employees of the company. Traditional onsite auditing for a shorter period focusing on hotspots and unclear areas was finally considered. This assumed that one system was completely traditional and the other was a hybrid of the digital and traditional systems. The study methodology involved modelling using standard life cycle assessment methods for the upstream, use and downstream impacts, to simplify comparisons between the totally paper-based system and the partial electronic auditing system. The analysis focused on energy consumption because it is major source of $\mathrm{CO}_{2}$ emissions worldwide. The other impacts were not included in this analysis, but they were alluded to as part of the discussion.

\section{Energy and Environmental Implications of Internet and Teleconferencing}

\subsection{Net auditing experiences at NEC}

This study was prompted by the successful application of the partly electronic auditing service model by NEC Japan. (NEC, 2001) The company implemented the world's first known Environmental ISO 14001 audit employing an electronic system called Net Audit, which uses the shared information system utilizing the Internet and intranet information management resources. Audits were done effectively by an ISO 14001 certification body, connected to the company through Internet. The system consists of three types of auditing. There is Net Auditing, which enables the auditors to confirm the rules and regulations of the company through the Internet. There is Net Interview, which involves tails videoconferencing with top management and a final onsite traditional auditing limited to hotspots and grey areas. Videoconferencing is essentially communication across long distances with video and audio contact and may also include graphics and data exchange. Digital video transmission systems typically consist of a camera, coder-decoder, network access equipment, a network, and an audio system. The importance of onsite auditing is that it checks the actual operations and incorporates any questions that arise from the first two methods. The electronic system was used by the Japan Quality Assurance 
Organization, the largest certification body in Japan. Even thought this system has been regularly used, there has been no known scientific study that compares this new model to the old traditional system. This study therefore attempts to fill this gap. The questions that need to be resolved are to do with the assessing the energy implications of using ICT in environmental auditing, how this compares with traditional auditing models focusing on the Japanese automotive industry.

There are claims that Net Audit at NEC has many advantages, for example that about $60 \%$ of the auditing work, such as inspection of records, rules and regulations can be covered by accessing the environmental information systems through the Internet. (NEC, 2001) The actual onsite inspection time of the system is then reduced to less than half when compared to conventional auditing systems. Another argument is that because of the detailed preparations associated with the method, on-site inspection becomes more focused and thorough since the auditors are able to inspect the company's paper work at their own pace and at their own premises. The distributed management systems located at a number of different sites can now have records being examined at the offices of the auditors. The auditors have the advantage of being able to obtain sufficient information in advance hence they can use onsite auditing time more efficiently and effectively. The assumption is that the period of auditing will be reduced whenever electronic methods are applied. Other gains noted at NEC are that the auditors have been able to reduce the time for the inspection of management operations to $25 \%$ of the total original auditing time, time for interviews with top executives and managers has been maintained at the same level and the time for the inspection of documents and records has been reduced to $5 \%$ of the original total auditing time. Total auditing time reduction of $60 \%$ and the approximate reduction in carbon dioxide emissions estimated at 46\% were achieved. (NEC, 2001) However these emission reduction claims are not verified by indicating the models and the nature of the data used. In the absence of such analysis and evaluation, this study attempts a first cut into this problem.

\subsection{Benefits expected from ICT use in auditing}

The benefits expected in using ICT in environmental auditing are, cost savings from avoided travel business allowances, avoided time losses and reduced hotel costs. Some studies indicate that videoconferencing and audio conferencing systems have a payback period of less than one month. (Arnfalk, 2000) The challenge is to manage these systems so that in reality teleconferencing replaces travel as opposed to being a complimentary way of communicating or being a way of generating more travel through new electronic business contacts. Teleconferencing equipment is more energy intensive than normal telephony and some studies have identified the need to ensure that the equipment is used significantly. Studies 
done in Sweden (Arnfalk, 2002) and globally have shown that ignoring the energy used in the production of trains and airplanes, but taking into account manufacturing of videoconferencing equipment, train travel and air travel had 5 times and 10 times more impacts than a videoconferencing system if such systems were used at least 30 hours a week. Equipment left continuously in standby mode and hardly used had impacts comparable to train travel, but continued to be more favourable than air travel. (Arnfalk, 2002; GeSI UNEP, 2002) The analysis for the Japanese situation done is this paper used a different methodology and assumptions to explore different alternatives. An attempt was made to incorporate manufacturing cycle energy for cars, trains and airplanes also. Furthermore for auditing systems, all long distance transport substitution is not achievable, since the auditors still need to carry out at least one onsite inspection. Travel substitution is only possible at the local area, assuming that the number of days required to conduct the audit are reduced. The different transportation modes were considered for comparative analysis.

Some studies have shown that, ignoring manufacturing and delivery cycles of transportation equipment, videoconferencing has clear benefits over air travel and that if such travel substitution led to reduction of flights as opposed to number of passengers only, $\mathrm{CO}_{2}$ emissions from video conferencing could be less than $1 \%$ of those of a journey by air. (GeSI UNEP, 2002) For cumulative energy input and assuming a four-hour videoconference 12 times per year, videoconferences have been shown to have an advantage over business trips by train further than $30 \mathrm{~km}$, by diesel car further than $10 \mathrm{~km}$ and by petrol car further than $8 \mathrm{~km}$. (GeSI UNEP, 2002) The introduction of ultra low emission vehicles, like the hybrid cars, which are now a common feature in Japan and the consideration of the manufacturing energy of transportation equipment, introduces a new dimension in this study.

The members of the North American Communications Environmental Excellence Initiative (CEEI) have also estimated huge $\mathrm{CO}_{2}$ savings from telephone and video conferencing. (GeSI UNEP, 2002) The models for such analysis are in the process of being developed and life cycle analysis is not an exact science, hence requiring more modelling and experimentation for a variety of scenarios. The focus of this research is therefore on microscopic analysis of videoconference applications The typical auditing process was modelled in order to independently and scientifically evaluate the related energy impacts. Claims of energy benefits of partial electronic auditing have to be taken with care hence the need for a thorough and independent analysis to identify the critical variables in such systems and how they affect the overall system energy and environmental performance as was done in this paper.

\section{Modelling energy use in environmental auditing}


Environmental auditing normally follows basic steps consisting of: pre-audit activities, on-site activities and post-audit activities as indicated in Table 1. (Young, 1994) The onsite activities have some aspects, which can be shortened or modified when using electronic systems, for example physical meetings can be replaced by teleconferences. The initial plans for the fieldwork and collection of documentation, information, and records and the exit meeting can be done electronically at the auditors' offices. The model will therefore focus on the on-site activities and the electronic presite activities, since the pre-audit and post audit activities are assumed to be similar. The access to environmental management system documentation through Internet or e-mail using a computer for the partial electronic auditing system and the reading of the paper-based version posted by the company to be audited for the traditional system at the auditors' office are taken into account. In the case of the electronic version, the documents can be saved on a local PC after being downloaded from the audited company's website. This reduces energy use compared to reading them on the Internet directly. Given these boundaries, a comparison of traditional auditing and electronic auditing is as shown in Table 2 .

\section{Table 1 The steps followed in the traditional environmental audit}

\section{PRE-AUDIT ACTIVITIES}

1. Define audit objectives and scope

2. Communicate with audited facility: schedule audit and share audit protocol

3. Identify, request and review background information: like previous audit reports; copies of relevant rules and regulations; corporate plans, goals, objectives, targets and policies; facilities layout and organization

4. Select audit resources, that is resources appropriate for the objective and scope of the audit

5. Develop an audit plan: this is based on audit, organization, scope and agreed criteria for the year; identification of priority topics and assignment of audit teams to specific tasks

ON-SITE ACTIVITIES

1. Hold open meeting: between Auditor and company management for the purpose of discussing audit scope

2. Plan and supervise fieldwork: The team leader supervises the fieldwork and this is conducted according to protocol and plan

3. Identify, understand and access management control system: The audit team obtains information on significant control system elements, evaluation of control system effectiveness done.

4. Collect audit evidence: the information must be relevant, accurate and sufficient to support findings, conclusions and recommendations

5. Analyze and evaluate evidence

6. Ensure factual accounting: Documentation should be sufficient so that another auditor can come to similar conclusion; working papers to be consistent with established policy or audit scope

7. Conduct interim communication: The audit findings should be communicated periodically

8. Draft report: This should be provided with all significant findings to management, before issuance of the final report

9. Hold formal exit meeting: This is done when the on-site portion of the audit is complete to report all significant findings to management

POST AUDIT ACTIVITIES

1. Prepare final audit report: Resolve open issues; findings and their significance included in final report, signed by auditor and delivered to client.

2. Develop corrective action plan: This is top management responsibility and auditor contributes if requested to in the scope of work 
Table 2 Time line for typical traditional and proposed electronic audit

\begin{tabular}{|c|c|c|}
\hline Time & Activities-Traditional Auditing & Activities Electronic Auditing \\
\hline $\begin{array}{ll}\text { Day } & 1 \\
\text { am }\end{array}$ & $\begin{array}{l}\text { Interview top management and } \\
\text { environmental and/or regulatory officers }\end{array}$ & $\begin{array}{l}\text { Videoconference Interview top } \\
\text { management and environmental and/or } \\
\text { regulatory officers }(6 \mathrm{hrs})\end{array}$ \\
\hline $\begin{array}{ll}\text { Day } & 1 \\
\text { pm }\end{array}$ & Brief facility tour & $\begin{array}{l}\text { Electronic inspection and review of files } \\
(6 \mathrm{hrs})\end{array}$ \\
\hline $\begin{array}{l}\text { Day } 2 \\
\text { am }\end{array}$ & Inspect and review files & Detailed facility tour (6 hours) \\
\hline $\begin{array}{ll}\text { Day } 2 \\
\text { pm }\end{array}$ & Detailed facility tour & Continue facility tour (6 hours) \\
\hline $\begin{array}{l}\text { Day } 3 \\
\text { am }\end{array}$ & Continue facility tour & Visit regulatory agency (4 Hours) \\
\hline $\begin{array}{ll}\text { Day } & 3 \\
\text { pm }\end{array}$ & Continue facility tour & $\begin{array}{l}\text { Videoconference-staff and exit interview } \\
\text { (6 hrs) }\end{array}$ \\
\hline $\begin{array}{ll}\text { Day } & 4 \\
\text { am }\end{array}$ & Visit to regulatory agency & \\
\hline $\begin{array}{ll}\text { Day } & 4 \\
\text { pm }\end{array}$ & $\begin{array}{lll}\begin{array}{l}\text { Interview facility } \\
\text { clarifications }\end{array} & \text { regulatory staff- } \\
\end{array}$ & \\
\hline $\begin{array}{ll}\text { Day } & 5 \\
\text { am }\end{array}$ & Exit interview with facility personnel & \\
\hline
\end{tabular}

In the case of electronic auditing, there is no brief facility tour undertaken. The detailed facility tour is limited to one day, since it focuses on hotspots and areas that need more detailed inspection only. The interviews are also limited in time so that any necessary interviews with regulatory staff to answer unclear regulatory issues and the exit interviews are scheduled for the afternoon of the third day. A time reduction of two days is therefore assumed for electronic auditing compared to the purely traditional system since most documentation and records will have been processed and nonessential inspections eliminated. NEC achieved similar time savings using Net Audit and this strengthens the assumption. (NEC, 2001) The model therefore includes these two days only for transportation, accommodation and other aspects of the study. The two systems are then subjected to a comparative analysis to evaluate energy and environmental implications associated.

The facilities that are ISO 14001 certified in the car industry in Japan considered for the purpose of this study, are as shown in Table 3.

\section{Table 3 ISO 14001 certified facilities in the Japanese automotive industry-year ended 31 March 2002}

\begin{tabular}{|l|l|}
\hline Company name & Name of facility \\
\hline $\begin{array}{l}\text { Daihatsu Motor } \\
\text { Co. Ltd. }\end{array}$ & $\begin{array}{l}\text { Kyoto plant, Head Office Ikeda Plant, Shiga Ryuo Plant, Toda Plant, Domestic } \\
\text { Service Division, Sales and Service Training Center, Nishinomiya Parts Center }\end{array}$ \\
\hline $\begin{array}{l}\text { Honda Motor } \\
\text { Co., Ltd. }\end{array}$ & $\begin{array}{l}\text { Saitama Wako Plant, Saitama Sayama Plant, Tochigi Takanezawa Plant, } \\
\text { Tochigi Haga Plant } \\
\text { Tochigi Mohka Plant, Hamamatsu Factory, Hamamatsu Hosoe Plant, Suzuka } \\
\text { Plant, Kumamoto Factory, Honda Motorcycle Japan Co., Ltd., Aoyama Head } \\
\text { Office }\end{array}$ \\
\hline $\begin{array}{l}\text { Isuzu Motors } \\
\text { Ltd. }\end{array}$ & $\begin{array}{l}\text { Hokkaido plant, Kawasaki Plant, Fujisawa Plant, Tochigi Plant, Engineering } \\
\text { Division }\end{array}$ \\
\hline
\end{tabular}




\begin{tabular}{|c|c|}
\hline $\begin{array}{l}\text { Mazda Motor } \\
\text { Corporation }\end{array}$ & $\begin{array}{l}\text { Hiroshima Head Office Plant, Hiroshima Miyoshi Plant, Hofu Nakanoseki } \\
\text { plant, Hofu Nishinoura plant, Nihon Climate Systems Co., Ltd., Mazda E \& T } \\
\text { Co., Ltd., Toyo Eitech Co., Ltd., Mazda Ashtec Co., Ltd., Mazda Ace Co., Ltd., } \\
\text { Malox Co., Ltd., Keyrex Co., Ltd, Microtechno Co., Ltd., Kurashiki Synthetic } \\
\text { Chemical Industries Co., Ltd., Yoshiwa Industrial Co., Ltd., Mazda } \\
\text { Component Industry Co. Ltd. }\end{array}$ \\
\hline $\begin{array}{l}\text { Mitsubishi } \\
\text { Motors } \\
\text { Corporation }\end{array}$ & $\begin{array}{l}\text { Nagoya Plant, Kyoto plant, Mizushima Plant, Truck \& Bus Kawasaki Plant, } \\
\text { Pajero Manufacturing Co., Ltd., Mitsubishi Automotive Engineering Co., Ltd., } \\
\text { Pabco Co., Ltd., Mizushima Industries Co., Ltd. }\end{array}$ \\
\hline $\begin{array}{lr}\text { Nissan } & \text { Motor } \\
\text { Company } & \text { Co., } \\
\text { Ltd. } & \end{array}$ & $\begin{array}{l}\text { Oppama Plant, Tochigi plant, Nissan Shatai Co., Ltd. Production Facilities, } \\
\text { Yokohama Plant } \\
\text { Nissan Shatai Co., Ltd. Product Development Process, Iwaki Plant, Nissan } \\
\text { Kohki Co., Ltd., Product Development Process, Kyushu plant, Zama Business } \\
\text { Office, JATCO Co., Ltd., Aichi Machine Industry Co., Ltd. Atsuta Plant, } \\
\text { Rhythm Corporation, Gokyu Plant }\end{array}$ \\
\hline $\begin{array}{l}\text { Subaru-Fuji } \\
\text { Heavy Industries } \\
\text { Ltd. }\end{array}$ & $\begin{array}{l}\text { Gunma Main Plant, Yajima plant, Ohta North Plant, Oizumi Plant, } \\
\text { Utsunomiya Main Plant, Utsunomiya South Plant, Utsunomiya South No. } 2 \\
\text { Plant, Handa Plant, Saitama Manufacturing Plant, Bus Manufacturing and } \\
\text { House Pre-fabricating Division, Tokyo Office }\end{array}$ \\
\hline $\begin{array}{l}\text { Suzuki Motor } \\
\text { Corporation }\end{array}$ & $\begin{array}{l}\text { Iwata plant, Kosai Plant, Osuka Plant, Sagara Plant, Takatsuka Plant, } \\
\text { Toyokawa Plant, Suzuki Toyama Auto Parts Manufacturing Co., Ltd., Suzuki } \\
\text { Hamamatsu Auto Parts Manufacturing Co., Ltd., Suzuki Precision Industries } \\
\text { Co., Ltd., Suzuki Akita Auto Parts Manufacturing Co., Ltd. }\end{array}$ \\
\hline $\begin{array}{l}\text { Toyota Motor } \\
\text { Corporation }\end{array}$ & $\begin{array}{l}\text { Takaoka Plant, Tsutsumi plant, Motomachi plant, Tahara Plant, Kamigo } \\
\text { Plant, Kinuura Plant, Shimoyama Plant, Myochi plant, Kasugai Housing } \\
\text { Works, Yamanashi Housing Works, Miyoshi Plant, Honsha Plant, Teiho Plant, } \\
\text { Hirose Plant, Tochigi Housing Works }\end{array}$ \\
\hline $\begin{array}{l}\text { Total } \\
\text { No. }\end{array}$ & 97 \\
\hline
\end{tabular}

Sources: Daihatsu, 2002; Honda, 2002; Isuzu, 2002; Mazda, 2002; Mitsubishi, 2002; Nissan, 2002; Subaru- Fuji; Suzuki, 2002; Toyota, 2002

\subsection{Traditional system modelling}

The life cycle assessment model system boundaries for the traditional auditing system were transportation of the auditors, accommodation for the auditors, production of paper and the printing of the documents used. The model analyses the following: Energy use in the production of paper used for documentation and in paper disposal; Printing energy use for the auditing related paper documents; Energy use while reading the company's environmental documentation; and energy use in the transportation of the auditors and energy use at the hotel where the auditors are housed. There are basically two models used for this analysis. The first one is for the situation when the auditors' office is in the same area as the company that is being audited and only local travel is required. The total energy used $E$ given by $E=E_{p}+E_{p r}+E_{r}+E_{l}$

Where $E_{p}$ is the life cycle energy use for paper production

$E_{p r}$ is the energy used to print the documents used for environmental management auditing

$E_{r}$ is energy used for reading the documents

$E_{l}$ is the energy used for local travel by the auditors 
The second model is when the company is so far that the auditors have to travel a long distance and stay in a hotel. The total energy $E$ in this case is given by $\mathrm{E}=\mathrm{E}_{\mathrm{p}}+\mathrm{E}_{\mathrm{pr}}+\mathrm{E}_{\mathrm{r}}+\mathrm{E}_{1}+\mathrm{E}_{\text {hotel }}+\mathrm{E}_{\mathrm{t}}$

Where $E_{p}, E_{p r}, E_{r}, E_{l}$ are as defined earlier and

$E_{\text {hotel }}$ is the energy used for hotel accommodation.

$E_{t}$ is the energy used travelling from the office to the company far away by car, train or airplane.

It is assumed that the auditors are situated in four different distance zones and that the choice of transportation mode depends on the distance from the facility that is being audited. The transportation of the auditors for different modes of transport is shown in Figure 2. The model is defined as follows

- Distance of less than $200 \mathrm{~km}$ roundtrip per day, use a private car to and from the plant, no need to use hotel accommodation and local auditors do the external audit for the facility;

- Between 100 and $1000 \mathrm{~km}$ one way, use a car and stay in a hotel;

- Between 200 and $1000 \mathrm{~km}$ one way, use train and changeover to a taxi or hired car to and from the terminal railway station and for local trips and stay in a hotel; and

- Between 300 and $1000 \mathrm{~km}$ use a train to the airport, an airline to the airport closest to the facility that is being audited and a car to the facility and for local trips and stay in a hotel.

This enables a comparison of these different modes of transportation when the audited company and the auditors' office are between $300 \mathrm{~km}$ and $1000 \mathrm{~km}$ apart. The auditing of companies located more than $300 \mathrm{~km}$ away involves the use of a car, train or airplane to cover the long distance. In all cases, a car is used for local travel and this is assumed to be similar to the situation when the company being audited and the auditors' office are in the same area. This involves travel between the hotel and the company and may involve travel to the airport or railway station also. The use of the bus and ship were not considered because of the times taken by the bus and the ship and the added inconvenience involved in using the ship for most inland areas. 


\section{Figure 2: Traditional Auditing System Scenarios for local and long distance travel by different modes}

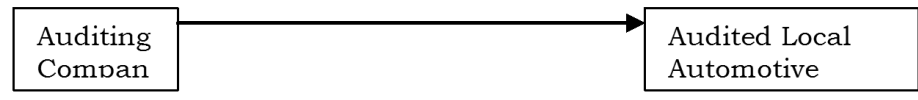

Travel by car or train for 5

Travel by train to and from

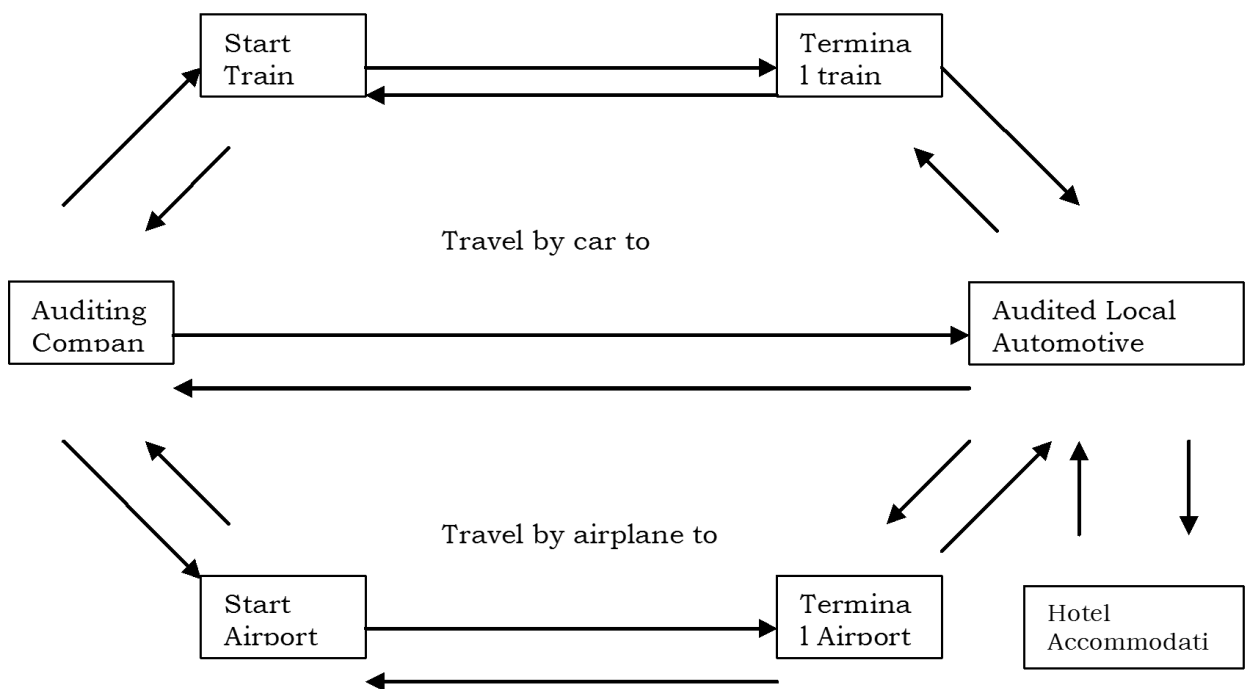

3.2 Modelling partial use of electronic methods in environmental auditing

Figure 3 shows the partly electronic auditing system. The life cycle assessment model system boundaries used were; transportation of the auditors, accommodation for the auditors, the use of videoconferencing equipment, the use of servers and PCs to enable Internet access of the documents by the two auditors. Two PCs and a server are needed on both the auditors and the audited company's premises. The transportation and hotel accommodation energy difference is due to the fact that the auditing is planned for a 3-day period compared to a 5-day period for the traditional system. The model analyses the following:

1. The energy use in transportation of the auditors and for hotel accommodation;

2. Energy use for reading documents at the audited company. This was taken to be the same as for traditional auditing; 
3. Energy use by the two PictureTel videoconferencing systems at the two companies;

4. Energy use by 4 PCs and 2 servers used for videoconferencing and information storage/exchange; and

5. Energy use by the ICT network equipment.

The total energy use $T$ for the partly electronic auditing system is therefore modelled as follows:

$$
\mathrm{T}_{\mathrm{e}}=\mathrm{T}_{\mathrm{t}}+\mathrm{T}_{\mathrm{a}}+\mathrm{T}_{\mathrm{r}}+\mathrm{T}_{\mathrm{v}}+\mathrm{T}_{\mathrm{c}}+\mathrm{T}_{\mathrm{s}}+\mathrm{T}_{\mathrm{n}}
$$

Where $T_{t}$ is the energy use for transporting the auditors

$T_{a}$ is the energy used at the hotel

$T_{r}$ is energy used for reading the documents

$T_{v}$ is the energy used for the videoconferencing system

$T_{c}$ is the energy used by the personal computers

$T_{s}$ is the energy used by the servers

$T_{n}$ is the energy used by the telecommunications and computer network

Figure 3: Configuration of the electronic audit system

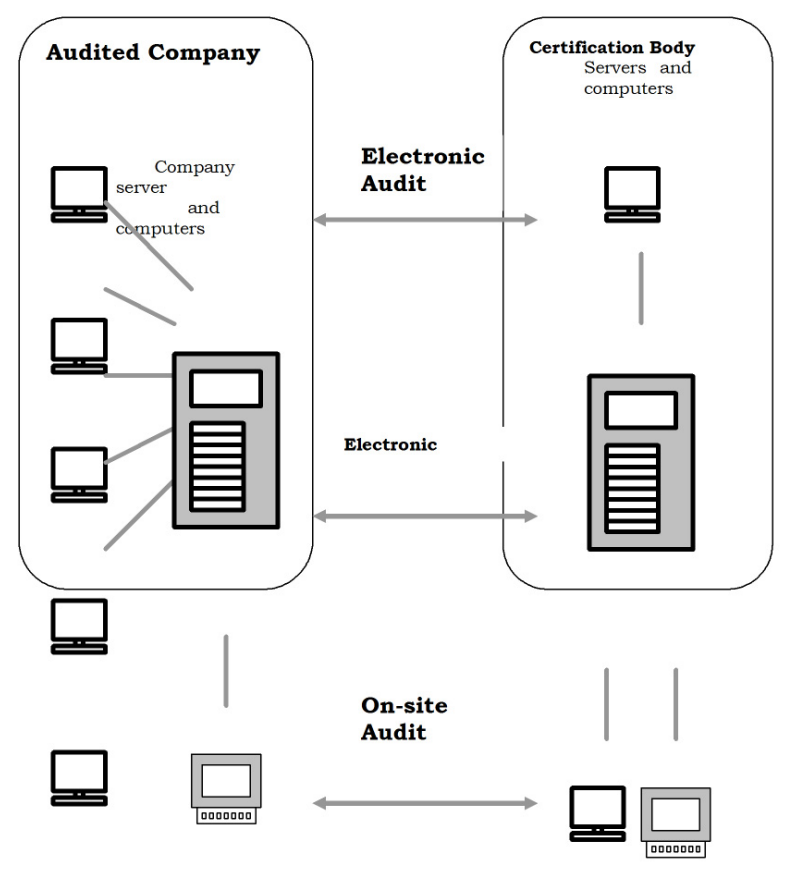


The energy used for transportation $T_{t}$, for hotel accommodation $T_{a}$ and for reading the documents $T_{r}$ is derived from the earlier completely traditional auditing model for a 3-day period. However the other energy usage has to be modelled and computed from the beginning. A general equation is defined for the production life cycle energy use in $\mathrm{MJ} E_{\text {prod }}$ as follows:

$\mathrm{E}_{\text {prod }}=$ Number of equipment used $x$ Total usage time in hours $x$ Production cycle energy in $M J$

Life span of equipment in unit times $x$ Total usage hours per unit time The energy consumption during equipment use in $\mathrm{MJ} E_{\text {use }}$ is given by:

$\mathrm{E}_{\text {use }}=\quad$ Number of equipment used $x$ total equipment usage time in seconds $x$ system power consumption in megawatts(MW)

The energy use by the equipment in standby mode in $\mathrm{MJ} E_{\text {standby }}$ is calculated using the following formula:

Estandby $=$ Number of equipment used $x$ equipment standby power consumption in MW x equipment time usage in seconds

The standby usage time does not include the time when the equipment is used at full power.

\section{Data collection and analysis}

This section describes the data used and the assumption behind its usage for the traditional and partly electronic auditing systems.

\subsection{Energy use in production $\left(E_{p}\right)$ and disposal of paper used in audit documentation}

The paper industry is one of the most energy and resource intensive industries. For each ton of paper avoided, $\mathrm{CO}_{2}$ savings are 3.3 metric tons for newspapers and 3.8 metric tons for office paper. (Cohen, 2001) Roughly $29.54 \mathrm{MJ}$ is required to make $1 \mathrm{~kg}$ of packaging paper. (DEQ, 1999) Other estimates put the electricity consumption of paper production at $10785 \mathrm{kWh}$ per ton (38.83 MJ per $\mathrm{kg}$ ) implying that when other forms of energy are considered paper production consumes more energy. $24 \mathrm{MJ}$ of electricity is required per $\mathrm{kg}$ for recycled paper. (Baxter, CVG) Earth Systems, 2001 estimates the energy required for producing one ton of paper from virgin wood pulp at $16,320 \mathrm{kWh}(58.75 \mathrm{MJ}$ per $\mathrm{kg})$ and that required for producing a ton from waste paper at $5919 \mathrm{kWh}(21.3 \mathrm{MJ}$ per $\mathrm{kg})$. Williams et al, 2002 quoting data from the BUWAL database indicate that the energy required to produce cardboard packaging boxes form waste paper is in the range 24-44 MJ depending on the process. For the manufacture of more refined printing paper, the value provided by Earth Systems, 2001 is closer to the expected value. The life cycle energy for printing paper from virgin wood is therefore taken as $60 \mathrm{MJ}$ per $\mathrm{kg}$ and that for 
recycled paper is taken as $40 \mathrm{MJ}$ per $\mathrm{kg}$ in this study. An environmental management system involves a lot of paperwork in the form of procedures, programs, manuals on the environmental management systems and for training, environmental reports and operational instructions. It is estimated that about $1.5 \mathrm{~kg}$ of paperwork (500 pages) is sent to the auditors for pre-audit activities in the case of the traditional system. However for partly electronic auditing system, the documents are sent through Internet or email. The estimated life cycle energy of the paper used to make the full environmental management system documentation is therefore estimated as varying from $60 \mathrm{MJ}$ for recycled paper to 90 MJ for paper from virgin wood pulp. Assuming that the paper is transported $50 \mathrm{~km}$ using a 6-ton truck that consumes a litre of diesel for every $3.5 \mathrm{~km}$ and recycled, energy use for paper disposal is $0.14 \mathrm{MJ}$. This is negligible compared to paper production energy and is disregarded for this analysis.

\subsection{Energy use in printing auditing paper documents $E_{p r}$}

The Environmental Protection Agency of the United States estimates that a conventional laser printer operating for 9 hours a day throughout the year consumes $185 \mathrm{kWh}(666 \mathrm{MJ})$, assuming an Average power consumption of 56 W. (EPA, 2004) An investigation on desktop printers identified that an Epson printer EPL-6100L monochrome laser printer that can print 16 pages per minute and it has a maximum power consumption of $720 \mathrm{~W}$. (EPSON EPL-6100L) Assuming normal printing each page can be printed in 3.75 second consuming $2.7 \mathrm{~kJ}$. Another printer considered was a Brother HL-1070 laser printer that can print 10 pages per minute. Its warm up time and first page print time combined together is 45 seconds, with a resolution of up to $1200 \times 600 \mathrm{dpi}$ and a printing power consumption of $280 \mathrm{~W}$. Its standby power consumption is $60 \mathrm{~W}$ and sleep power consumption is $13 \mathrm{~W}$. (Brother Europe) Printing each page takes an average of 6 seconds consuming 1.68 $\mathrm{kJ}$. Ink jet printers consume less energy. Commercial printers for publications are bigger, more powerful and can print colours and pictures using more energy. The total print time depends on image complexity, image size, type of port used and network traffic; printer's memory configuration; print/quality mode selected; colour/correction mode selected; image smoothing activation and number of non-resident fonts used. Most colour printers are specified at 16 pages per minute black and white and 5 pages per minute full colour. The Phaser 750 Xerox colour printer is rated at $380 \mathrm{~W}$. (Phaser 750) Taking 12 seconds to print a colour page gives an energy consumption of $4.56 \mathrm{~kJ}$ per page. Many annual reports in the Japanese automobile industry are very colourful and the average energy consumption per page of the annual environmental report is taken as $3 \mathrm{~kJ}$ per page. The printing energy is therefore $1.5 \mathrm{MJ}$ for the 500 pages sent to the auditors. The life cycle energy use of the printer is ignored. 


\subsection{Energy use at Auditors' office reading company's environmental documents $E_{r}$}

This is mainly in the form of electricity use for lighting and heating. The measure of energy intensity in buildings is commonly expressed in annual average energy consumption per unit of floor area that is per square meter $\left(/ \mathrm{m}^{2}\right)$. The energy consumption depends on the heat ventilation and air condition (HVAC) and the lighting design mainly. The mean electric load is of the order of $10-100 \mathrm{~W} / \mathrm{m}^{2}$. Electric intensive rooms, like data centres, have energy intensities of 100$1000 \mathrm{~W} / \mathrm{m}^{2}$. (Aebischer et al, 2002) Japan Airlines estimates electricity consumption by office buildings of $244 \mathrm{kWh}(878.4 \mathrm{MJ})$ per square meter per year and heating at 24.6 litres kerosene per square meter based on its total floor area of $690,263 \mathrm{~m}^{2}$. (JAL, 2001) The energy content of kerosene, which is commonly used for heating in Japan, is the same as that of jet fuel, which is 5,670 Btus per barrel ( 37.63 $\mathrm{MJ} /$ litre). (EPA, 2001) Heating energy is therefore estimated to be $925.7 \mathrm{MJ} / \mathrm{m}^{2}$ per year and the total annual energy consumption $1804.1 \mathrm{MJ} / \mathrm{m}^{2}$. The average power consumption of a building becomes $57.2 \mathrm{~W} / \mathrm{m}^{2}$. This is in agreement with figures quoted earlier. Assuming that auditors working on the company documents need 4 hours during the afternoon of the first day of auditing $0.82 \mathrm{MJ} / \mathrm{m}^{2}$ of energy would be used. If the office area is assumed to be $20 \mathrm{~m}^{2}$, the energy use becomes 16.5 MJ.

\subsection{Energy use in transporting $\left(E_{l}\right.$ and $\left.E_{t}\right)$ and accommodating the auditors $E_{\text {hotel }}$}

The use of a car for auditing a company close to the auditors' office is considered first. It is assumed that a total distance of $200 \mathrm{~km}$ a day is covered using a gasoline car that consumes fuel at 10 kilometres per litter $(\mathrm{km} / \mathrm{L})$. For a 5 -day audit, a total distance of $1000 \mathrm{~km}$ is covered consuming 100 litres of gasoline. The energy used in the manufacture of a car is quoted as 83 GJ. (Herring, 2001) This gives a $11.5 \%$ contribution to life cycle energy use, if car lifespan is taken as $200,000 \mathrm{~km}$ at $10 \mathrm{~km} /$ liter, in agreement with literature. Energy use in the production of vehicles and fuel used by the vehicle is incorporated using a factor of 1.24 , since some studies have indicated that energy to produce a fuel is $13 \%$ of its energy content and the production phase of a private car accounts for $11 \%$ of its life cycle energy use. (Williams et al, 2002) The local distance is modelled for rail transportation also and a factor of 1.14 is applied to incorporate manufacturing energy. The same factor is used for airplane.

One of the Japanese railway companies, JR East reduced the energy intensity in its passenger operations from $20.6 \mathrm{MJ} / \mathrm{car}-\mathrm{km}$ to 18.8 $\mathrm{MJ} /$ car-km in year 2001. Such improvements in efficiency help to ensure that the energy and environmental impacts of rail passengers are reduced. The company used a total of 56.4 million MJ in 2001, equivalent to 1.46 million kiloliters of crude oil to transport 5.9 billion customers and emitted 2.29 million tons of carbon dioxide in the 
process. A comparison of the energy consumption and emission levels of the different modes of transport is shown in Table 4. (JR East, 2002)

Table 4 Comparison of energy use and $\mathrm{CO}_{2}$ emissions for different transportation modes

\begin{tabular}{|l|c|c|}
\hline Mode of transport & $\begin{array}{c}\text { Energy used per passenger- } \\
\mathbf{k m}\end{array}$ & $\begin{array}{l}\mathbf{C O}_{\mathbf{2}} \\
\text { passenger-km }\end{array}$ \\
\hline Japan Railways East & $0.34 \mathrm{MJ}$ & $15 \mathrm{~g}$ \\
\hline Other Japanese Railways & $0.43 \mathrm{MJ}$ & $18 \mathrm{~g}$ \\
\hline Bus & $0.61 \mathrm{MJ}$ & $99 \mathrm{~g}$ \\
\hline Private cars & $2.72 \mathrm{MJ}$ & $172 \mathrm{~g}$ \\
\hline Airlines & $1.66 \mathrm{MJ}$ & $110 \mathrm{~g}$ \\
\hline
\end{tabular}

\section{Source: (JR East, 2002)}

The total revenue passenger-kilometres for Japan Airlines for the year ended $31^{\text {st }}$ March 2001 were 90,492 million. The available seatkilometres were 122,776 million, giving a revenue passenger load factor of $73.7 \%$. (JAL, 2001) The fuel consumption for the airplanes varies between $1.76 \times 10^{-2}$ and $2.71 \times 10^{-2} \mathrm{~kg}$ per seat-km. Using the fact that one ton of jet oil has a volume of 1260.72 litres (EPA, 2001), the fuel use is $2.22 \times 10^{-2}$ and $3.42 \times 10^{-2}$ litres / seat-km. Using the above load factor and $37.63 \mathrm{MJ} /$ litre of jet fuel, the energy consumption per passenger-km is between 1.13 and $1.76 \mathrm{MJ} /$ passenger-km. This range agrees with the value given by JR East in the above table. A value of $1.66 \mathrm{MJ} /$ passenger- $\mathrm{km}$ is used in the model.

Hotels use energy for various purposes. A study at the University of Central Florida, of energy saving in Caribbean hotels showed that energy consumption by usage area was; air conditioning $56 \%$; water heating $7 \%$; Fans, pumps and others $12 \%$, lighting $11 \%$ and refrigeration $14 \%$. These ratios can be used to obtain $\mathrm{CO}_{2}$ emissions if the type of fuel used is known. Electric water heaters consumed an average $210 \mathrm{kWh}$ per day. On average, each of the 70-roomed hotels consumed $91300 \mathrm{kWh}$ per month, about $43.48 \mathrm{kWh}(156.53 \mathrm{MJ})$ per room per day. (FSEC, 2003) Some hotel bathrooms use 4 incandescent bulbs, 60W each, resulting in an annual consumption of $600 \mathrm{kWh}$ (2160 MJ) per year or $6 \mathrm{MJ}$ per day for one room only. (EETD Newsletter, 2003) However a more comprehensive study at the University of Florida, for hotels in Florida gives average usage of water at 300 gallons per month, varying from 99 to 1,045 per occupied room. Average energy use is $218 \mathrm{kBtu}$ per occupied room per month, with a range of 92 to $426 \mathrm{kBtu}$ per occupancy per month. The total energy use index varied between 41,000 and $136,000 \mathrm{Btu} / \mathrm{ft}^{2} /$ year. (West Mike) Data on Japanese hotels is lacking. The energy use index for Japanese hotels was therefore taken as $160 \mathrm{MJ}$ per room per day based on the data from the Caribbean hotels. 


\subsection{Extra energy use for transportation and hotel accommodation in traditional system}

Additional energy consumption due to the traditional systems was found to be 1,729 $\mathrm{MJ}$ for transportation (392 $\mathrm{MJ}$ if rail used) and 640 MJ for hotel use.

\subsection{Energy use by the videoconferencing equipment $T_{v}$}

A PictureTel Venue 2000 Model 30 is specified to have a power consumption of 300 Watts (W). (PictureTel Venue 2000, 2004) Other videoconferencing systems like PictureTel Concorde are shown to have a maximum power rating of $1200 \mathrm{VA}$, with an electronic module rated at $469 \mathrm{~W}$ and a typical monitor rated at $240 \mathrm{~W}$. (PictureTel Concorde 4500, 2004) Portable video conferencing systems are rated at $40 \mathrm{~W}$, with a maximum power consumption of 100 VA. (SwiftSite II, 2004) In this case, the use of a PictureTel Venue 2000 model 30 at a power rating of $300 \mathrm{~W}$, including the monitor was assumed. This has the following specifications: It can conduct a point-to-point (two sites) or multi-point (3 or more sites) videoconference; It can scan, zoom in and out at speaker or conference participants; It shows a pre-recorded VHS tape to viewers if required; Records the current videoconference on VHS tape if required; Displays black and white or colour paper printouts and transparencies; Interfaces a laptop and shows software application demonstrations or PowerPoint slide shows; Can have a computer dial-up via modem connection; Displays 35MM slides through a slide carousel. The auditor and the company sites being audited have the same type of equipment made up of the following equipment: Monitor PictureTel Venue 2000 coder-decoders; PictureTel camera; PictureTel area pancake microphone; Bose Speaker; Cannon RE-350 Video Visualiser; 2-VHS cassette recorders (one for playback, one for recording); Laptop external video interface for demonstrating software or showing PowerPoint slide shows; A 35MM Slide Carousel; A speaker phone that may also double for an internet dial-up connection; and One PictureTel Montage 570 Multipoint Conferencing Unit (MCU). The MCU has the capability to do bridging, can do voice activated switching for multi-point conferences and can accept up to 3 simultaneous $(384 \mathrm{~Kb})$ ISDN connections through a primary interface (PRI) line.

The limitations are that the MCU can only send or receive at $384 \mathrm{~Kb}$ and the video is only 15 frames per second compared to a regular video which operates at 30 frames per second. All coders-decoders are directly connected to the PictureTel MCU, either through copper cabling or via sub-rated $\mathrm{T} 1384 \mathrm{~Kb}$ connection. The energy to produce a colour television has been given as 2,800 MJ. (Herring, 2001) It is assumed that all the equipment specified for videoconferencing requires more production energy than a normal colour television and a figure of $4,000 \mathrm{MJ}$ is used. The videoconferencing time has been set at 12 hours for the whole 
auditing process. Assuming that the life cycle of the PictureTel system is 5 years, with a usage rate of 20 hours a week the share of production life cycle energy use is calculated as $18.46 \mathrm{MJ}$. The energy during the use phase of the videoconferencing system in $\mathrm{MJ}$ based on the assumption that the maximum power consumption of the PictureTel system is $300 \mathrm{~W}$ and that it actually operates at that power, is found to be $25.92 \mathrm{MW}$. It is assumed that the system is on standby during the 3-day auditing period whenever it is not used and its power consumption in that mode is $40 \mathrm{~W}$. This gives the standby energy as 17.28 MJ.

\subsection{Energy use by PCs $T_{c}$}

The production and delivery cycle of computer consists of the energy use to produce and deliver one computer, which has been quoted at 8,300 MJ. (Williams et al, 2002) Some authors have estimated the production and supply chain cycles energy use for desktop computers at $6004 \mathrm{MJ}$ using the traditional model, $5823 \mathrm{MJ}$ using the integrated model with air shipping and $5320 \mathrm{MJ}$ using the integrated model with ground shipping. (Cohen, 2001) Others have given higher estimates of between 10 and 12 GJ. (Herring, 2001) The production and delivery life cycle energy consumption of each PC is taken as $6000 \mathrm{MJ}$. Using the models, the production life cycle energy consumption assuming the usage of $4 \mathrm{PCs}$, whose life span is 5 years for 3 days for the auditing purpose only is $29.59 \mathrm{MJ}$. This assumes the office computers are used an average of 8 hours a day and that computers are also used during teleconferencing. Assuming that the PCs have a power consumption of $150 \mathrm{~W}$ the energy consumption during the usage phase of the computer is $38.88 \mathrm{MJ}$. The standby energy for the 4 computers, assuming $10 \mathrm{~W}$ power consumption during that mode is $7.78 \mathrm{MJ}$.

\subsection{Energy use by server $T_{s}$}

It is assumed in this case that the server is a bigger computer, whose production and delivery life cycle energy use is 12,000 $\mathrm{MJ}$ and that each one exists at the auditor's office and at the audited company. Using the model the life cycle energy consumption of a server is taken as 65.75 MJ. For the purposes of this study, it is assumed that the two servers at the two companies are dedicated to environmental auditing only for the 3-day period. The servers are switched on 24 hours a day hence in standby mode whenever not in use. A usage time of 6 hours is assumed for e-mail transfer, file transfer and electronic review of files. The use phase of the server is found to consume $12.96 \mathrm{MJ}$. The standby mode, assuming a power consumption of $40 \mathrm{~W}$, consumes $19.01 \mathrm{MJ}$.

\subsection{Energy use for the network $T_{n}$}

Energy used by the networking and telecommunications equipment 
is very difficult to estimate due to lack of data. These include the public telephone network analogue or digital, internet protocol network, port of presence network, firewall, secure socket layer accelerator, cell site equipment, transmission cables like fibre optic, private branch exchanges, local area network switches, load balancers, routers, hubs, wide area network switches, remote access servers and cable model termination systems to facilitate the use of Internet. (Matthews, 2002: Miyamoto, 2001: Roth, 2002) Estimates have put the energy consumption per telephone line at 90-144 kWh/ year per line. (Herring, 2001) This includes space heating at the exchanges, running the exchange equipment, operating air conditioning and ventilation systems and power used by the telephone line. The levels of energy consumption when taken at a national level are high. For example Computer networks and telecommunication networks consumed 6.2 TWh and 6.4 TWh respectively in year 2000. (Roth, 2002) The energy consumption of the networking and telecommunications equipment is therefore taken as $288 \mathrm{kWh}$ per year per telephone line at most, assuming that computer networks consume the same amount of energy as the telecommunication network. Assuming that two telephone lines are used, the network energy is $566 \mathrm{kWh}(2,074 \mathrm{MJ})$ per year. Under these assumptions the energy consumed using the network for 18 hours is $4.26 \mathrm{MJ}$. The data used in the model are summarised in Table 5 .

Table 5 Data sets used for inventory analysis of the traditional and electronic system

\begin{tabular}{|c|c|c|}
\hline Process or aspect & Data Source & Values and comments \\
\hline $\begin{array}{l}\text { Paper production life } \\
\text { cycle energy }\end{array}$ & $\begin{array}{l}\text { BULWAL database, Williams } \\
\text { et al, } 2002 \text { and Earth } \\
\text { Systems Website }\end{array}$ & $\begin{array}{l}30-60 \mathrm{MJ} / \mathrm{kg} \text {. Lowest values for recycled } \\
\text { paper and highest values for office paper } \\
\text { from virgin wood }\end{array}$ \\
\hline Paper $\mathrm{CO}_{2}$ emissions & Cohen, 2002 & $\begin{array}{l}3.3 \text { tons } \mathrm{CO}_{2} \text { per ton of newsprint paper, } \\
3.8 \text { ton } \mathrm{CO}_{2} \text { per ton of office paper }\end{array}$ \\
\hline $\begin{array}{l}\text { Power consumption } \\
\text { of printer for various } \\
\text { modes }\end{array}$ & $\begin{array}{l}\text { USA } \\
\text { Protection Anvironmental } \\
\text { Epson and Brother }\end{array}$ & $\begin{array}{l}230-720 \text { W. Depends on printer speed } \\
\text { and color. Standby power } 30-60 \mathrm{~W}\end{array}$ \\
\hline $\begin{array}{l}\text { Energy content of } \\
\text { petroleum fuels }\end{array}$ & $\begin{array}{ll}\text { Environmental } & \text { Protection } \\
\text { Agency USA, 2001 } & \end{array}$ & $\begin{array}{l}34.86 \mathrm{MJ} / \text { liter of gasoline; } 38.66 \mathrm{MJ} / \mathrm{L} \text { of } \\
\text { diesel and } 37.63 \mathrm{MJ} / \mathrm{L} \text { of jet-fuel- } \\
\text { kerosene }\end{array}$ \\
\hline $\begin{array}{l}\text { Energy intensity of } \\
\text { buildings }\end{array}$ & $\begin{array}{l}\text { Aebischer et a,1 2002; Japan } \\
\text { Airlines } 2001\end{array}$ & $\begin{array}{l}10-100 \mathrm{~W} / \mathrm{m}^{2} \text { normally and } 100-1000 \\
\mathrm{~W} / \mathrm{m}^{2} \text { for energy intensity rooms }\end{array}$ \\
\hline $\begin{array}{l}\text { Car } \\
\text { production/delivery } \\
\text { life cycle energy, \% of } \\
\text { total }\end{array}$ & $\begin{array}{l}\text { Herring, 2001; Williams et al, } \\
2002\end{array}$ & $\begin{array}{l}\text { Average of } 83 \text { GJ. Production/delivery } \\
\text { about } 11 \% \text { of total life cycle energy of car. }\end{array}$ \\
\hline $\begin{array}{l}\text { Life cycle energy of } \\
\text { fuel } \\
\text { production/deliver }\end{array}$ & Williams et al, 2002 & 13 of the fuel's energy content. \\
\hline
\end{tabular}




\begin{tabular}{|c|c|c|}
\hline $\begin{array}{lr}\mathrm{CO}_{2} & \text { emission } \\
\text { coefficients } & \text { for } \\
\text { Japanese Railway, } \\
\text { Ship and air } \\
\text { transportation }\end{array}$ & $\begin{array}{l}\text { Environmental reports- } \\
\text { Toyota, 2001; Japan Railways } \\
\text { East, 2002 and Japan } \\
\text { Airlines (JAL), } 2001\end{array}$ & $\begin{array}{l}\text { In grams } \mathrm{CO}_{2} \text { per ton-kilometer, Railways } \\
21.7 \text {; Coastal services 35.6; Air } 806 \\
\text { (available ton-km) or } 110 \text { g per passenger- } \\
\text { kilometer }\end{array}$ \\
\hline $\begin{array}{l}\text { Energy use per ton- } \\
\text { kilometer for different } \\
\text { modes of transport }\end{array}$ & $\begin{array}{ll}\text { Japan } & \text { Railways } \\
\text { environmental report, } 2001\end{array}$ & $\begin{array}{l}\text { In } \mathrm{MJ} / \text { passenger-kilometer; } \\
0.34-0.43 \text {; Builways } \\
\text { airlines 1.66. }\end{array}$ \\
\hline $\begin{array}{l}\text { Fuel consumption } \\
\text { coefficients for } \\
\text { different } \\
\text { transportation modes }\end{array}$ & $\begin{array}{l}\text { Environmental Reports- } \\
\text { Japanese car makers, 2002; } \\
\text { Japan Railways East, 2002; } \\
\text { and JAL (2001) }\end{array}$ & $\begin{array}{l}\text { Airplane }(1.76-2.71) \times 10^{-2} \mathrm{~kg} \text { fuel/seat- } \\
\mathrm{km} \text { or } 0.327 \text { liters per ton-km. } \\
\text { Coefficients for trucks and cars from } \\
\text { Japanese Automotive makers' reports. }\end{array}$ \\
\hline $\begin{array}{l}\text { Energy consumption } \\
\text { per hotel room per } \\
\text { day }\end{array}$ & $\begin{array}{l}\text { FSEC, 2003; West Mike, } \\
\text { 1998; EETD Newsletter, } 2003\end{array}$ & $160 \mathrm{MJ}$ per hotel room per day. \\
\hline $\begin{array}{l}\text { Videoconferencing } \\
\text { system production } \\
\text { life cycle energy }\end{array}$ & $\begin{array}{lrr}\text { Herring, } 2001 \text { and } & \text { own } \\
\text { assumptions based } & \text { on } \\
\text { television figures } & & \end{array}$ & $\begin{array}{l}4000 \mathrm{MJ} \text {, between a personal computer } \\
(6000 \mathrm{MJ}) \text { and a television ( } 2800 \mathrm{MJ}) \text {. }\end{array}$ \\
\hline $\begin{array}{l}\text { Life span } \\
\text { videoconferencing } \\
\text { equipment }\end{array}$ & $\begin{array}{l}\text { Makers' information and own } \\
\text { assumptions }\end{array}$ & $\begin{array}{l}5 \text { years assuming a usage rate of } 20 \\
\text { hours per week during that time }\end{array}$ \\
\hline $\begin{array}{l}\text { Videoconferencing } \\
\text { equipment power } \\
\text { consumption }\end{array}$ & $\begin{array}{l}\text { Estimations and makers' } \\
\text { information }\end{array}$ & $\begin{array}{l}\text { 300W during system use and } 40 \mathrm{~W} \text { during } \\
\text { standby mode. }\end{array}$ \\
\hline $\begin{array}{l}\text { Personal Computer } \\
\text { (PC) production and } \\
\text { supply life cycle } \\
\text { energy }\end{array}$ & $\begin{array}{l}\text { Cohen, 2001; Herring, 2001; } \\
\text { Williams et al, } 2002\end{array}$ & $\begin{array}{l}\text { Assumption of } 6000 \mathrm{MJ} / \mathrm{PC} \text { based on } \\
\text { these data sources }\end{array}$ \\
\hline $\begin{array}{l}\text { PC and monitor } \\
\text { power consumption } \\
\text { during use }\end{array}$ & $\begin{array}{l}\text { Environmental Protection } \\
\text { Agency website, EV Solar, } \\
\text { Williams et al, 2002 }\end{array}$ & $\begin{array}{l}150 \text { Watts combined consumption based } \\
\text { on average of } 70 \mathrm{~W} \text { for } \mathrm{PC} \text { and } 80 \mathrm{~W} \text { for } \\
\text { Monitor; standby consumption of } 10 \mathrm{~W}\end{array}$ \\
\hline PC life span & $\begin{array}{l}\text { Estimation, } \\
\text { information }\end{array}$ & 5 years for intermittent use \\
\hline & $\begin{array}{l}\text { Williams et al 2002, Cohen } \\
2001 \text { and Herring } 2001\end{array}$ & $\begin{array}{l}\text { Assumed value of } 12000 \mathrm{MJ} / \text { server } \\
\text { based the mentioned data sources. }\end{array}$ \\
\hline Life span of a server & $\begin{array}{l}\text { Computer } \\
\text { information }\end{array}$ & 3 years for ubiquitous use \\
\hline $\begin{array}{ll}\text { Server } & \text { energy } \\
\text { consumption } & \end{array}$ & $\begin{array}{l}\text { Estimation, } \\
\text { information }\end{array}$ & $300 \mathrm{~W}, 40 \mathrm{~W}$ in standby mode \\
\hline $\begin{array}{lr}\text { Network } & \text { energy } \\
\text { consumption } & \text { per } \\
\text { telephone line } & \end{array}$ & $\begin{array}{l}\text { Herring, 2001; Roth et al, } \\
2002\end{array}$ & $2074 \mathrm{MJ}$ per telephone line per year \\
\hline
\end{tabular}

\section{Results and Discussion}

Assuming that a distance of $200 \mathrm{~km}$ is covered per day for auditing a company within the locality of the auditor for 5 days, commuter rail use if possible results in usage of $980 \mathrm{MJ}$ of energy for the transport during the whole exercise compared to the use of a car at 4,323 MJ as shown in Figure 4. The figure also compares energy usage when a facility $1,000 \mathrm{~km}$ away is audited using different modes of transport. The transport energy use $\left(E_{l}\right.$ plus $\left.E_{t}\right)$ is $8,645 \mathrm{MJ}$ for a car, 5,303 MJ for a train and 8,107 $\mathrm{MJ}$ for an airplane. In the case where a train and an airplane is used for travel, a car is assumed to be used for local travel between the hotel and the audited company. 
Figure 4: Transportation energy in MJ for different transportation modes for local auditing and for a facility 1000 km away

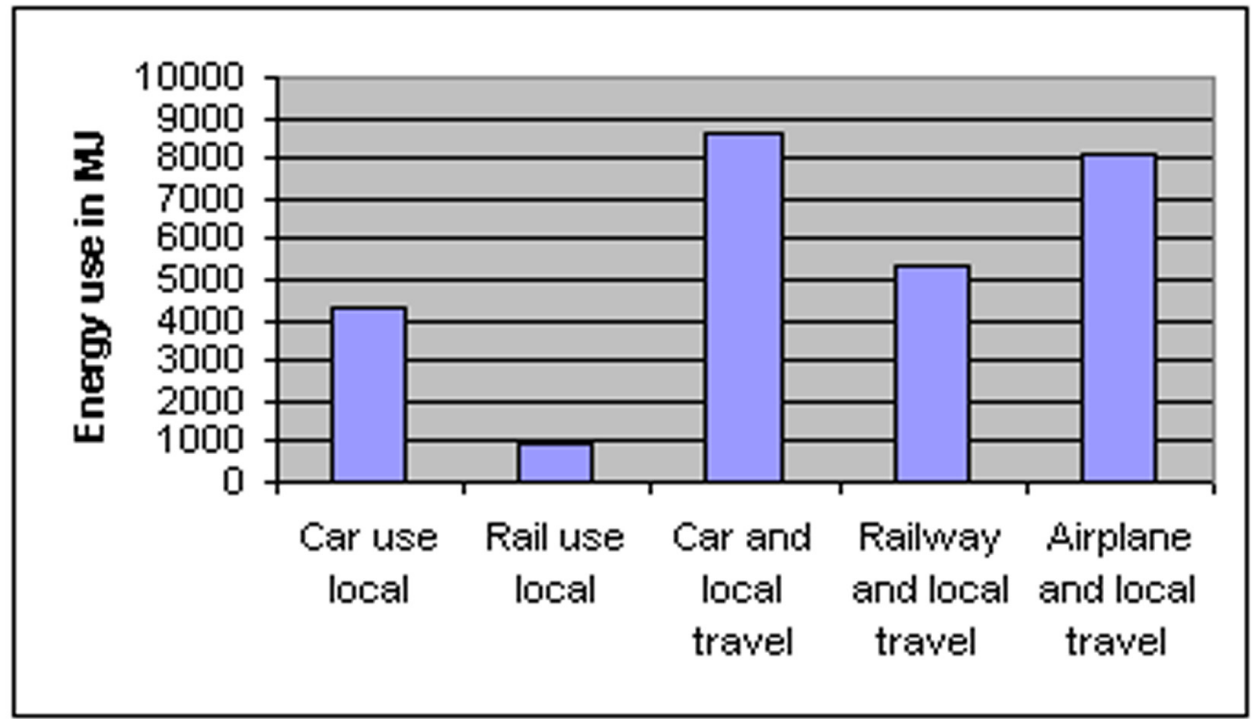

Energy use is calculated for two auditors staying in the hotel for 5 days. The total energy use $E$ for the different transportation modes is shown in the following figure 5 .

\section{Figure 5: Energy requirements for the different scenarios}

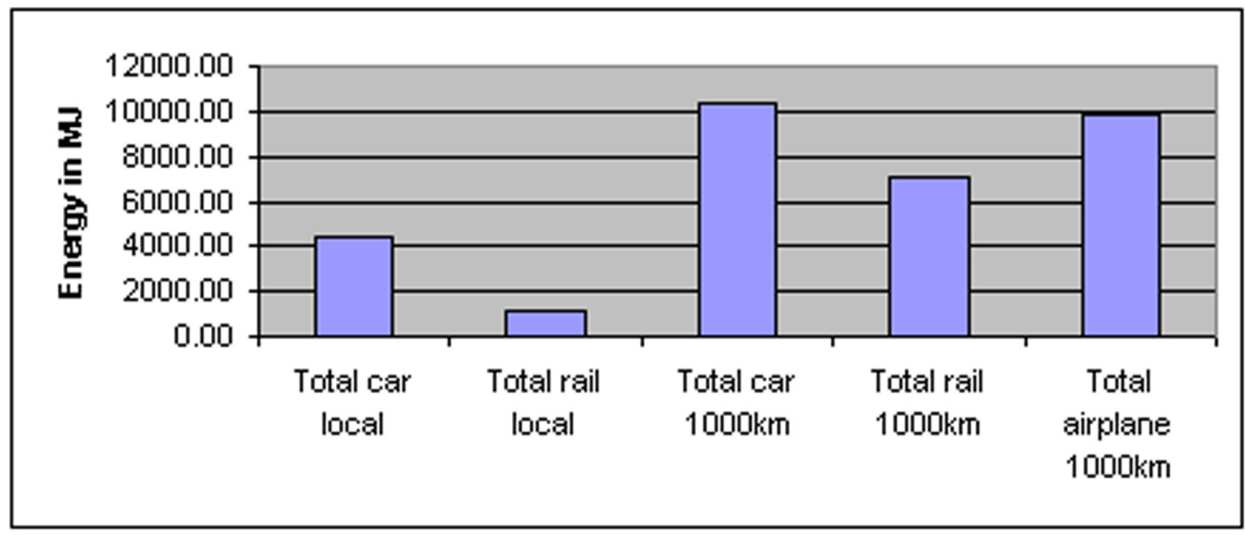

The results demonstrate the advantage of using railway transport instead of a car for local audits. The energy use contribution from the use of paper, printing and when reading the documents is minimal, reflecting the central role transportation takes in energy consumption. The use of a hotel results in higher energy usage. The results, model assumptions and constants are shown in Table 6. 


\section{Table 6 Energy used in the traditional auditing model}

Travel dominates the energy consumption as shown in Figure 6 for an audited company, which is $1000 \mathrm{~km}$ away form the auditors' office and for local auditing activities only, the right side part of the figure.

\begin{tabular}{|l|l|l|l|}
\hline Paper from new wood energy MJ/kg & 60 & Total distance km & 2000 \\
\hline Recycled paper energy MJ/kg & 40 & Transportation energy MJ & 8545 \\
\hline Document mass kg & 1.5 & Number of auditors & 2 \\
\hline New wood Paper total energy MJ & 90 & Number of nights at hotel & 5 \\
\hline Recycled paper total energy MJ & 60 & Gasoline energy content MJ/L & 34.86 \\
\hline Printing energy in MJ/page & 0.003 & Railway energy/passenger-km MJ & 0.43 \\
\hline No. of pages printed & 500 & Airplane energy/passenger-km MJ & 1.66 \\
\hline Total printing energy MJ & 1.5 & Railway use energy MJ & 980 \\
\hline Area of office used by auditors m2 & 20 & Airplane energy use MJ & 3785 \\
\hline Energy consumption MJ/m2 & 1804.1 & Car use local & 4323 \\
\hline Time to read documents hrs & 4 & Car only 1000 km & 4323 \\
\hline Energy use reading docs. MJ & 16.5 & Rail use local energy MJ & 980 \\
\hline Distance/day local audit km & 200 & Car and local travel energy MJ & 8645 \\
\hline No. of audit days & 5 & Railway and local travel energy MJ & 5303 \\
\hline Gasoline consumption km/L & 10 & Airplane and local travel energy MJ & 8107 \\
\hline $\begin{array}{l}\text { Total energy used by car local travel } \\
\text { MJ }\end{array}$ & 4323 & Total car local & \\
\hline Hotel energy/occupancy/day MJ & 160 & Total rail local & 4431 \\
\hline Total hotel energy use MJ & 1600 & Total car 1000km & 1088 \\
\hline Auditor to company distance km & 1000 & Total rail 1000km & 10353 \\
\hline Local travel distance km & 1000 & Total airplane $1000 \mathrm{~km}$ & 7011 \\
\hline
\end{tabular}

This is followed by energy spent at the hotel and the rest is almost comparatively insignificant.

\section{Figure 6: Energy Use for the different activities of traditional auditing}
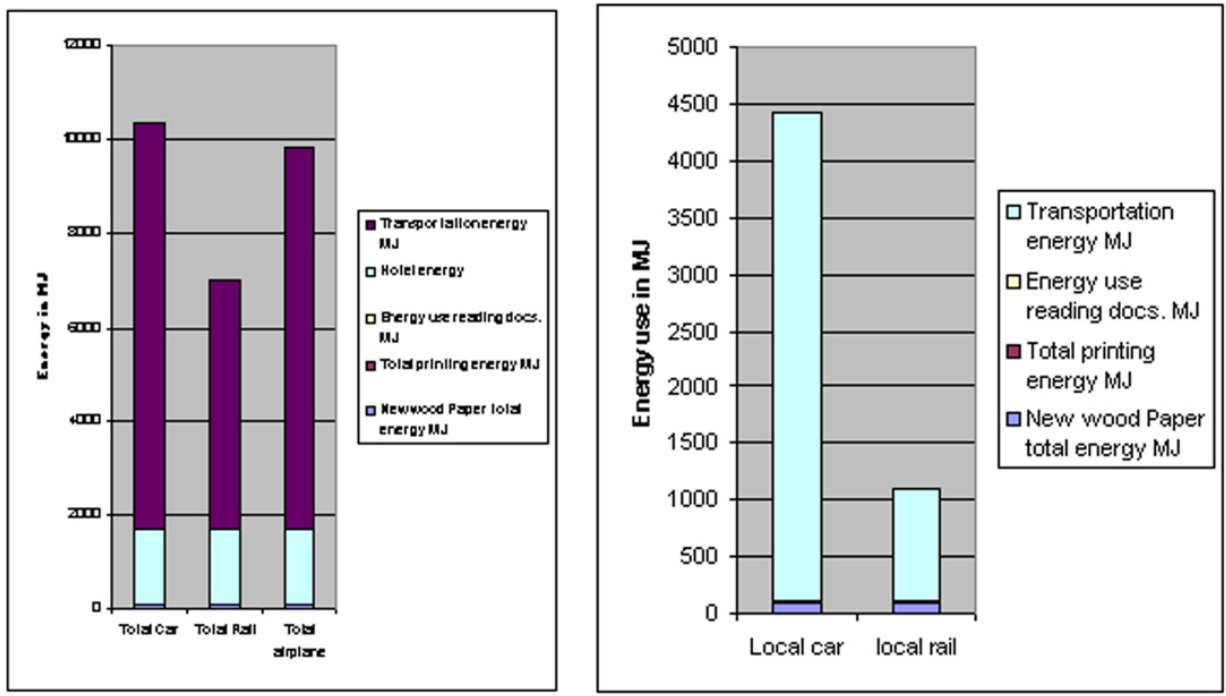

Distance of $1000 \mathrm{~km}$ - Auditor to company 


\subsection{Total electronic auditing energy}

The energy share for $T_{v}, T_{c}, T_{s}$ and $T_{n}$ is shown in the following chart as Figure 7. Networking apparently consumes the lowest energy, several times smaller than the other three types. The total energy consumption is calculated as $240 \mathrm{MJ}$.

\section{Figure 7: Energy use for the electronic auditing part}

5.2 Comparison of total energy consumption for traditional and partial electronic auditing

The energy comparisons were done for three scenarios. The first one

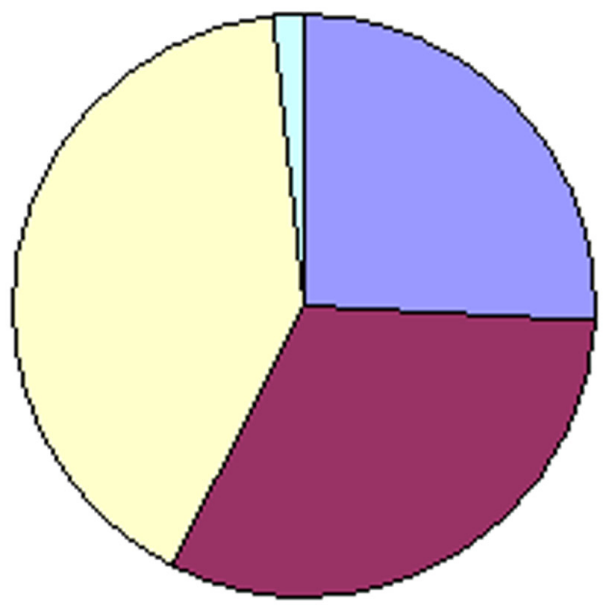

\begin{tabular}{|l}
\hline Total PictureTel \\
energy 61.66 \\
$\square$ Total computer \\
energy $76.25 \mathrm{MJ}$ \\
$\square$ Total Server energy \\
$97.72 \mathrm{MJ}$ \\
$\square$ Total network energy \\
$4.26 \mathrm{MJ}$
\end{tabular}

is when the distance travelled is $300 \mathrm{~km}$. This is considered as the minimum distance over which the three modes of transport can be reasonably compared. The next one considers a distance of $650 \mathrm{~km}$ and finally a distance of $1000 \mathrm{~km}$. The results were found to have similar conclusions, that is traditional auditing systems used more energy. The results for the last scenario are shown in Figure 8. A summary of the results, model assumptions and constants is shown in Table 7. 
Figure 8: Comparison of energy consumption of traditional and partial electronic auditing for a company $1000 \mathrm{~km}$ away

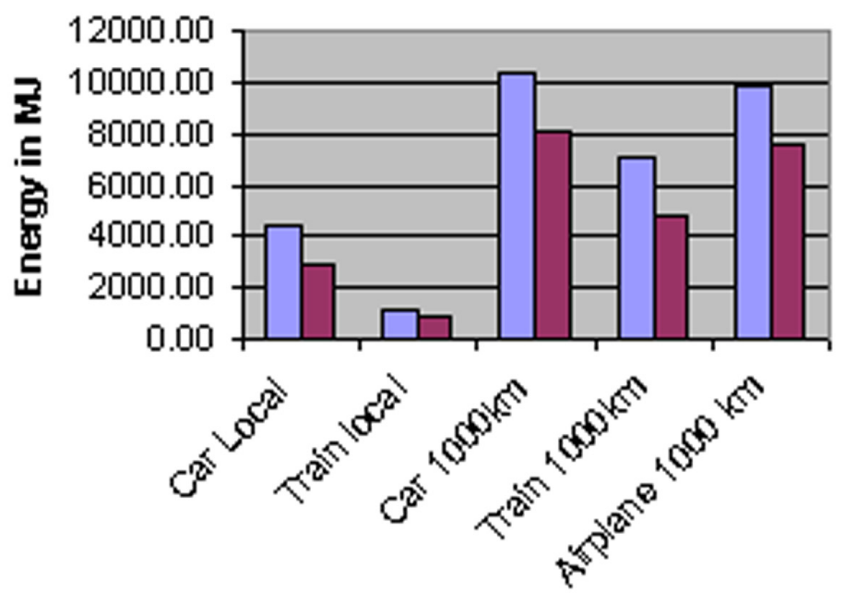

口Traditional

Partly electronic

In both cases, that is, traditional auditing and partly electronic auditing, the major contributor of energy consumption was transportation followed by hotel accommodation. Railway transport

\begin{tabular}{|l|l|l|l|}
\hline Partly electronic audit days & 3 & Total network energy 4.26 MJ & 4.26 \\
\hline Total transport energy local car MJ & 2594 & Life span of PictureTel yrs & 5 \\
\hline Transport energy difference car MJ & 1729 & PictureTel power consumption W & 300 \\
\hline Total transport energy local rail MJ & 588 & Total videoconferencing time hrs & 12 \\
\hline Transport energy difference rail MJ & 392 & No. of PictureTel systems & 2 \\
\hline Hotel energy use MJ & 960 & PictureTel standby power use W & 40 \\
\hline Hotel energy difference MJ & 640 & PictureTel usage time/week hrs & 20 \\
\hline Total energy difference MJ & 2369 & No. of computers used for audit & 4 \\
\hline Energy Manufacturing PictureTel MJ & 4000 & Computer life span yrs & 5 \\
\hline PictureTel auditing cycle energy MJ & 18.46 & Computer power consumption W & 150 \\
\hline Energy PictureTel Use MJ & 25.92 & Computer usage hours & 18 \\
\hline & & Computer standby power consumption & 10 \\
\hline Standby energy PictureTel MJ & 17.28 & W & 2 \\
\hline Computer manufacturing energy MJ & 6000 & No. of servers used & 300 \\
\hline Computer auditing cycle energy MJ & 29.59 & Power consumption of server W & 40 \\
\hline Energy use all computers MJ & 38.88 & Server standby power consumption & 3 \\
\hline Standby energy computers MJ & 7.78 & Server life span & 6 \\
\hline Server manufacturing energy MJ & 12000 & Server usage time hrs & 2074 \\
\hline Server auditing cycle energy MJ & 65.75 & Network energy MJ/telephone line/yr & 2850 \\
\hline Energy use servers MJ & 12.96 & Partly electronic car local MJ & 845 \\
\hline Standby energy servers MJ & 19.01 & Partly electronic rail local MJ & 8133 \\
\hline Total electronic auditing & 239.89 & Partly electronic car $1000 \mathrm{~km}$ & 4790 \\
\hline Total PictureTel energy 61.66 & 61.66 & Partly electronic rail 1000 km & 7595 \\
\hline Total computer energy 76.25 MJ & 76.25 & Partly electronic airplane $1000 \mathrm{~km}$ & \\
\hline Total Server energy 97.72 MJ & 97.72 & & \\
\hline
\end{tabular}




\begin{tabular}{|l|l|l|l|}
\hline Standby energy PictureTel MJ & 17.28 & $\begin{array}{l}\text { Computer standby power consumption } \\
\text { W }\end{array}$ & 10 \\
\hline Computer manufacturing energy MJ & 6000 & No. of servers used & 2 \\
\hline Computer auditing cycle energy MJ & 29.59 & Power consumption of server W & 300 \\
\hline Energy use all computers MJ & 38.88 & Server standby power consumption & 40 \\
\hline Standby energy computers MJ & 7.78 & Server life span & 3 \\
\hline Server manufacturing energy MJ & 12000 & Server usage time hrs & 6 \\
\hline Server auditing cycle energy MJ & 65.75 & Network energy MJ / telephone line $/ \mathrm{yr}$ & 2074 \\
\hline Energy use servers MJ & 12.96 & Partly electronic car local MJ & 2850 \\
\hline Standby energy servers MJ & 19.01 & Partly electronic rail local MJ & 845 \\
\hline Total electronic auditing & 239.89 & Partly electronic car $1000 \mathrm{~km}$ & 8133 \\
\hline Total PictureTel energy 61.66 & 61.66 & Partly electronic rail $1000 \mathrm{~km}$ & 4790 \\
\hline Total computer energy 76.25 MJ & 76.25 & Partly electronic airplane $1000 \mathrm{~km}$ & 7595 \\
\hline Total Server energy 97.72 MJ & 97.72 & & \\
\hline
\end{tabular}

used the least amount of energy, about $845 \mathrm{MJ}$ for partial electronic auditing compared with 2,850 for a car. For long distances use of the car was found to have the most energy consumption, followed by the use of airplane and the use of the train had the least energy impacts. Using the train for long distances and hiring a car at the station closest to the auditing site can realize major energy savings compared to the use of a car all the way or use of a plane and hiring a car at the nearest airport. The use of local auditors should be given top priority to remove the energy impacts associated, extra transportation and accommodation.

Table 7 Energy use in the partly electronic model for a distance of $1000 \mathrm{~km}$

\begin{tabular}{|c|c|c|c|c|}
\hline $\begin{array}{ll}\text { Variable } & \text { Factor } \\
\text { considered } & \end{array}$ & $\begin{array}{l}\text { Base } \\
\text { Valu } \\
\text { e }\end{array}$ & $\begin{array}{l}\text { Plausible } \\
\text { Variatio } \\
\text { n }\end{array}$ & $\begin{array}{l}\text { Variation effect on } \\
\text { electronic energy use in } \\
\text { MJ (\% change) }\end{array}$ & $\begin{array}{l}\text { Variation effect } \\
\text { on traditional } \\
\text { energy use }\end{array}$ \\
\hline $\begin{array}{l}\text { Production life cycle energy } \\
\text { use of virgin wood paper } \\
\text { (MJ) }\end{array}$ & 60 & $\begin{array}{l}+10 \% \\
-30 \%\end{array}$ & $\begin{array}{l}10,362(+0.09 \%) \\
10,326(-0.27 \%)\end{array}$ & $\begin{array}{l}\text { None. Less energy } \\
\text { for part electronic } \\
\text { system }\end{array}$ \\
\hline $\begin{array}{l}\text { Production life cycle energy } \\
\text { use of recycled paper }(\mathrm{MJ})\end{array}$ & 40 & $\begin{array}{l}+10 \% \\
-25 \%\end{array}$ & $\begin{array}{l}10,329(+0.06 \%) \\
10,308(-0.15 \%)\end{array}$ & $\begin{array}{l}\text { None. Less energy } \\
\text { for part electronic } \\
\text { system }\end{array}$ \\
\hline $\begin{array}{l}\text { Mass of Audit Documents } \\
\text { used by the auditors (kg) }\end{array}$ & 1.5 & $\begin{array}{l}+300 \% \\
-50 \%\end{array}$ & $\begin{array}{l}10,623(+2.61 \%) \\
10,308(-0.43 \%)\end{array}$ & $\begin{array}{l}\text { None. Less energy } \\
\text { for part electronic } \\
\text { system }\end{array}$ \\
\hline $\begin{array}{l}\text { Energy used by printer per } \\
\text { page printed (KJ) }\end{array}$ & 3 & $\begin{array}{l}+300 \% \\
-50 \%\end{array}$ & $\begin{array}{l}10,358(+0.05 \%) \\
10,352(-0.01 \%)\end{array}$ & $\begin{array}{l}\text { None. Less energy } \\
\text { for part electronic } \\
\text { system }\end{array}$ \\
\hline $\begin{array}{l}\text { Number of pages of } \\
\text { auditing material printed }\end{array}$ & 500 & $\begin{array}{l}+500 \% \\
-50 \%\end{array}$ & $\begin{array}{l}10,361(+0.09 \%) \\
10,352(-0.01 \%)\end{array}$ & $\begin{array}{l}\text { None. Less energy } \\
\text { for part electronic } \\
\text { system }\end{array}$ \\
\hline $\begin{array}{l}\text { Office floor area used by } \\
\text { the auditors } \mathrm{m} 2\end{array}$ & 20 & $\begin{array}{l}+200 \% \\
-20 \%\end{array}$ & $\begin{array}{l}10,386(+0.31 \%) \\
10,350(-0.03 \%)\end{array}$ & $\begin{array}{l}8165(+0.41 \%) \\
8129(-0.04 \%)\end{array}$ \\
\hline $\begin{array}{l}\text { Energy consumption by } \\
\text { buildings in Japan } \\
\mathrm{MJ} / \mathrm{m} 2 / \text { year }\end{array}$ & 1804 & $\begin{array}{l}+20 \% \\
-20 \%\end{array}$ & $\begin{array}{l}10,356(+0.03 \%) \\
10,350(-0.03 \%)\end{array}$ & $\begin{array}{l}8136(+0.05 \%) \\
8128(-0.05 \%)\end{array}$ \\
\hline $\begin{array}{l}\text { Time taken to read the } \\
\text { audit documents in hours }\end{array}$ & 4 & $\begin{array}{l}+300 \% \\
-25 \%\end{array}$ & $\begin{array}{l}10,403(+0.47 \%) \\
10,349(-0.04 \%)\end{array}$ & $\begin{array}{l}8,182(+0.61 \%) \\
8,128(-0.05 \%)\end{array}$ \\
\hline $\begin{array}{l}\text { Distance-Auditing } \\
\text { company to client } \\
\text { company }\end{array}$ & 1000 & $\begin{array}{l}+200 \% \\
-70 \%\end{array}$ & $\begin{array}{l}18,998(+83.50 \%) \\
9,273(-10.43 \%)\end{array}$ & $\begin{array}{l}16,778(+79.01 \%) \\
7,052(-13.28 \%)\end{array}$ \\
\hline
\end{tabular}




\begin{tabular}{|c|c|c|c|c|}
\hline $\begin{array}{l}\text { Distance traveled by } \\
\text { auditors in kilometers per } \\
\text { day }\end{array}$ & 200 & $\begin{array}{l}+50 \% \\
-90 \%\end{array}$ & $\begin{array}{l}12,515(+20.88 \%) \\
6,463(-37.57 \%)\end{array}$ & $\begin{array}{l}9,429(+15.95 \%) \\
5,798(-28.70)\end{array}$ \\
\hline $\begin{array}{l}\text { Number of days taken to } \\
\text { complete a traditional } \\
\text { audit }\end{array}$ & 5 & $\begin{array}{l}+100 \% \\
-40 \%\end{array}$ & $\begin{array}{l}16,276(+56.00 \%) \\
7,984(-22.88 \%)\end{array}$ & $\begin{array}{l}\text { None. Less energy } \\
\text { for part electronic } \\
\text { system }\end{array}$ \\
\hline $\begin{array}{l}\text { Fuel efficiency of auditors' } \\
\text { vehicle } \mathrm{km} / \mathrm{L}\end{array}$ & 10 & $\begin{array}{l}+200 \% \\
-20 \%\end{array}$ & $\begin{array}{l}8,912(-13.92 \%) \\
12,516(+20.89 \%)\end{array}$ & $\begin{array}{l}6980(-14.17 \%) \\
9862(+21.28 \%)\end{array}$ \\
\hline $\begin{array}{l}\text { Hotel energy consumption } \\
\text { per occupant per day MJ }\end{array}$ & 160 & $\begin{array}{l}+25 \% \\
-25 \%\end{array}$ & $\begin{array}{l}10,753(+3.86 \%) \\
9,953(-3.86 \%)\end{array}$ & $\begin{array}{l}8,373(+2.96 \%) \\
7893(-2.94 \%)\end{array}$ \\
\hline $\begin{array}{l}\text { Number of auditors } \\
\text { required for the exercise }\end{array}$ & 2 & $\begin{array}{l}+100 \% \\
-50 \%\end{array}$ & $\begin{array}{l}11,953(+15.45 \%) \\
9,553(-7.73 \%)\end{array}$ & $\begin{array}{l}9,093(+11.82 \%) \\
7,653(-5.89 \%)\end{array}$ \\
\hline $\begin{array}{l}\text { Number of nights spent by } \\
\text { auditors at the hotel }\end{array}$ & 5 & $\begin{array}{l}+100 \% \\
-40 \%\end{array}$ & $\begin{array}{l}11,953(+15.45 \%) \\
9,713(-6.18 \%)\end{array}$ & $\begin{array}{l}\text { None. Less energy } \\
\text { for part electronic } \\
\text { system }\end{array}$ \\
\hline $\begin{array}{lr}\begin{array}{l}\text { Railway } \\
\text { consumption }\end{array} & \text { energy } \\
\text { passenger-kilometer } & \text { per } \\
\end{array}$ & 0.43 & $\begin{array}{l}+20 \% \\
-20 \%\end{array}$ & $\begin{array}{l}7,207 \quad(+2.80 \%) \quad \text { for } \\
\text { railway use } \\
6,815(-2.80 \%)\end{array}$ & $\begin{array}{ll}4,986 & (+4.10 \%) \\
\text { rail } & 4,594 \quad(- \\
4.10 \%) & \text { use } \\
\end{array}$ \\
\hline $\begin{array}{lr}\begin{array}{l}\text { Airline } \\
\text { consumption } \\
\text { passenger-kilometer }\end{array} & \text { per } \\
\end{array}$ & 1.66 & $\begin{array}{l}+20 \% \\
-20 \%\end{array}$ & $\begin{array}{l}10,572 \quad(+7.71 \%) \quad \text { for } \\
\text { airline use } \\
9,058(-7.71 \%)\end{array}$ & $\begin{array}{l}8,352 \quad(+9.97 \%) \\
\text { airline } \\
6,638(-9.97 \%) \text { use }\end{array}$ \\
\hline $\begin{array}{l}\text { Time required to complete } \\
\text { partially electronic audit } \\
\text { (days) }\end{array}$ & 3 & $\begin{array}{l}+100 \% \\
-35 \%\end{array}$ & $\begin{array}{l}\text { No change. Traditional } \\
\text { system can use less } \\
\text { energy. }\end{array}$ & $\begin{array}{l}11,804(+45.15 \%) \\
6,848(-15.79 \%)\end{array}$ \\
\hline $\begin{array}{lrr}\text { Life } \quad \text { span } & \text { of } \\
\text { videoconferencing } & \text { system } \\
\text { in years } & & \\
\end{array}$ & 5 & $\begin{array}{l}+100 \% \\
-40 \%\end{array}$ & $\begin{array}{l}\text { No effect. More energy for } \\
\text { traditional system }\end{array}$ & $\begin{array}{l}8123(-0.11 \%) \\
8,145(+0.16 \%)\end{array}$ \\
\hline $\begin{array}{l}\text { Videoconferencing system } \\
\text { power consumption } \mathrm{W}\end{array}$ & 300 & $\begin{array}{l}+300 \% \\
-50 \% \\
\end{array}$ & $\begin{array}{l}\text { No effect. More energy for } \\
\text { traditional system }\end{array}$ & $\begin{array}{l}8,210(+2.19 \%) \\
8,120(-0.15 \%)\end{array}$ \\
\hline $\begin{array}{lrr}\text { Total time ror } & \text { for } \\
\text { videoconferencing } & \text { during } \\
\text { auditing in hours } & \\
\end{array}$ & 12 & $\begin{array}{l}+50 \% \\
-50 \%\end{array}$ & $\begin{array}{l}\text { No effect. More energy for } \\
\text { traditional system }\end{array}$ & $\begin{array}{l}8,153(+0.26 \%) \\
8,112(-0.26 \%)\end{array}$ \\
\hline $\begin{array}{lr}\text { Number } & \text { of } \\
\text { videoconferencing } & \text { systems } \\
\text { used for auditing } & \\
\end{array}$ & 2 & $\begin{array}{l}+100 \% \\
-0 \%\end{array}$ & $\begin{array}{l}\text { No effect. More energy for } \\
\text { traditional system }\end{array}$ & $\begin{array}{l}8,194(+0.76 \%) \\
\text { No change }\end{array}$ \\
\hline $\begin{array}{l}\text { Videoconferencing standby } \\
\text { power use W }\end{array}$ & 40 & $\begin{array}{l}+50 \% \\
-50 \%\end{array}$ & $\begin{array}{l}\text { No effect. More energy for } \\
\text { traditional system }\end{array}$ & $\begin{array}{l}8,141(+0.11 \%) \\
8,124(-0.11 \%)\end{array}$ \\
\hline $\begin{array}{l}\text { Videoconference system } \\
\text { usage time in hours per } \\
\text { week }\end{array}$ & 20 & $\begin{array}{l}+100 \% \\
-50 \%\end{array}$ & $\begin{array}{l}\text { No effect. More energy for } \\
\text { traditional system }\end{array}$ & $\begin{array}{l}8,123(-0.11 \%) \\
8,151(+0.25 \%)\end{array}$ \\
\hline \begin{tabular}{lrr} 
Number & of & \multicolumn{2}{c}{ personal } \\
computers & used & for \\
auditing & & \\
\end{tabular} & 4 & $\begin{array}{l}+50 \% \\
-50 \%\end{array}$ & $\begin{array}{l}\text { No effect. More energy for } \\
\text { traditional system }\end{array}$ & $\begin{array}{l}8,171(+0.48 \%) \\
8.094(-0.48 \%)\end{array}$ \\
\hline $\begin{array}{l}\text { Personal computer life } \\
\text { span in years }\end{array}$ & 5 & $\begin{array}{l}+100 \% \\
-60 \% \\
\end{array}$ & $\begin{array}{l}\text { No effect. More energy for } \\
\text { traditional system }\end{array}$ & $\begin{array}{l}8,118(-0.17 \%) \\
8,177(+0.55) \\
\end{array}$ \\
\hline $\begin{array}{l}\text { Computer and monitor } \\
\text { power consumption } \mathrm{W}\end{array}$ & 150 & $\begin{array}{l}+40 \% \\
-60 \% \\
\end{array}$ & $\begin{array}{l}\text { No effect. More energy for } \\
\text { traditional system }\end{array}$ & $\begin{array}{l}8,148(+0.20 \%) \\
8,109(-0.28 \%)\end{array}$ \\
\hline $\begin{array}{l}\text { Personal computer usage } \\
\text { time for auditing in } \\
\text { hours/computer }\end{array}$ & 18 & $\begin{array}{l}+100 \% \\
-50 \%\end{array}$ & $\begin{array}{l}\text { No effect. More energy for } \\
\text { traditional system }\end{array}$ & $\begin{array}{l}8,203(+0.87) \\
8,098(-0.42)\end{array}$ \\
\hline Variable Factor considered & $\begin{array}{l}\text { Base } \\
\text { Value }\end{array}$ & $\begin{array}{l}\text { Plausible } \\
\text { Variation }\end{array}$ & $\begin{array}{l}\text { Variation effect on } \\
\text { electronic energy use in } \\
\text { MJ (\% change) }\end{array}$ & $\begin{array}{l}\text { Variation effect on } \\
\text { traditional energy } \\
\text { use }\end{array}$ \\
\hline $\begin{array}{l}\text { Standby power } \\
\text { consumption of a personal } \\
\text { computer W }\end{array}$ & 10 & $\begin{array}{l}+50 \% \\
-50 \%\end{array}$ & $\begin{array}{l}\text { No effect. More energy for } \\
\text { traditional system }\end{array}$ & $\begin{array}{l}8,136(+0.04 \%) \\
8,129(-0.04 \%)\end{array}$ \\
\hline $\begin{array}{lc}\text { Home } & \text { PC } \\
\text { production/delivery } & \text { life } \\
\text { cycle energy use (MJ) } & \end{array}$ & 6000 & $\begin{array}{l}+20 \% \\
-20 \%\end{array}$ & $\begin{array}{l}\text { No effect. More energy for } \\
\text { traditional system }\end{array}$ & $\begin{array}{l}8,138(+0.07) \\
8,127(-0.06)\end{array}$ \\
\hline $\begin{array}{l}\text { Server production/delivery } \\
\text { life cycle energy use (MJ) }\end{array}$ & $\begin{array}{l}1200 \\
0 \\
\end{array}$ & $\begin{array}{l}+20 \% \\
-50 \% \\
\end{array}$ & $\begin{array}{l}\text { No effect. More energy for } \\
\text { traditional system }\end{array}$ & $\begin{array}{l}8,146(+0.17 \%) \\
8,100(-0.39 \%) \\
\end{array}$ \\
\hline $\begin{array}{l}\text { Life span of the server } \\
\text { used by the company } \\
\text { (years) }\end{array}$ & 3 & $\begin{array}{l}+100 \% \\
-35 \%\end{array}$ & $\begin{array}{l}\text { No effect. More energy for } \\
\text { traditional system }\end{array}$ & $\begin{array}{l}8,100(-0.39) \\
8168(+0.44)\end{array}$ \\
\hline
\end{tabular}




\begin{tabular}{|l|l|l|l|l|}
\hline $\begin{array}{l}\text { Life span of the server } \\
\text { used by the company } \\
\text { years) }\end{array}$ & 3 & $\begin{array}{l}+100 \% \\
-35 \%\end{array}$ & $\begin{array}{l}\text { No effect. More energy for } \\
\text { traditional system }\end{array}$ & $\begin{array}{l}8,100(-0.39) \\
8168(+0.44)\end{array}$ \\
\hline $\begin{array}{l}\text { Server average power } \\
\text { consumption (Watts) }\end{array}$ & 300 & $\begin{array}{l}+3300 \% \\
-50 \%\end{array}$ & $\begin{array}{l}\text { No effect. More energy for } \\
\text { traditional system }\end{array}$ & $\begin{array}{l}8,560(+5.26 \%) \\
8,126(-0.06)\end{array}$ \\
\hline $\begin{array}{l}\text { Number of servers used } \\
\text { during the auditing } \\
\text { exercise }\end{array}$ & 2 & $\begin{array}{l}+100 \% \\
-0 \%\end{array}$ & $\begin{array}{l}\text { No effect. More energy for } \\
\text { traditional system }\end{array}$ & $\begin{array}{l}8,230(+1.21 \%) \\
\text { No change }\end{array}$ \\
\hline $\begin{array}{l}\text { Server standby power } \\
\text { consumption W }\end{array}$ & 40 & $\begin{array}{l}+50 \% \\
-50 \%\end{array}$ & $\begin{array}{l}\text { No effect. More energy for } \\
\text { traditional system }\end{array}$ & $\begin{array}{l}8,142(+0.12 \%) \\
8,123(-0.12 \%)\end{array}$ \\
\hline $\begin{array}{l}\text { Usage time for each server } \\
\text { during auditing in hours }\end{array}$ & 6 & $+100 \%$ & $\begin{array}{l}\text { No effect. More energy for } \\
\text { traditional system }\end{array}$ & $\begin{array}{l}8,144(+0.13 \%) \\
8,127(-0.06)\end{array}$ \\
\hline $\begin{array}{l}\text { Telecommunication/comp } \\
\text { uter network energy } \\
\text { use/year }(\mathrm{MJ})\end{array}$ & 2074 & $+50 \%$ & $\begin{array}{l}+100 \% \\
\text { No effect. More energy for } \\
\text { traditional system }\end{array}$ & $\begin{array}{l}8,137(+0.06) \\
8,130(-0.04)\end{array}$ \\
\hline
\end{tabular}

\subsection{Sensitivity analysis}

The results were tested for sensitivity for companies between 300 $\mathrm{km}$ and $1000 \mathrm{~km}$ away from the offices of the auditing company, as shown in Table 8 and this was found to mostly change the magnitudes of the energy consumed only. Partial electronic auditing systems consistently used lower energy. However the energy difference for local auditing using the railway system was only marginally in favour of partial and electronic auditing. The results were found to be very sensitive to the distance travelled per day during auditing.

Table 8 Sensitivity analyses of all the variables (for car use except when stated)

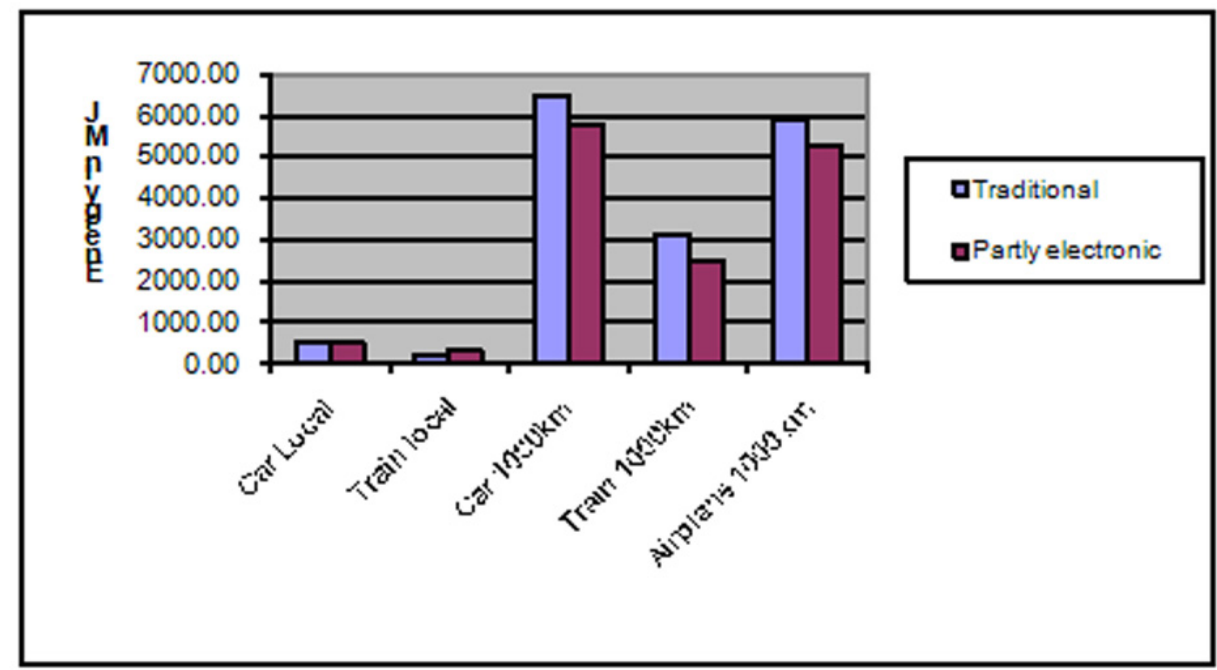

If the auditor travelled $20 \mathrm{~km}$ per day only instead of the assumed $200 \mathrm{~km}$ per day between the office and the company being audited, the results changed and they are as shown in Figure 9. The energy consumption for electronic auditing became higher than for 
traditional auditing for auditors that are in the same locality as the audited company when they used the train. Energy use for the car was almost the same for local traditional and partly electronic auditing. This seems to suggest that auditing of local companies is better done using traditional methods. The energy for rail transport in this case is $206 \mathrm{MJ}$ compared to $315 \mathrm{MJ}$ for electronic auditing. The use of a car for local audits at such a distance resulted in the two systems consuming almost the same amount of energy. The traditional system consumed $540 \mathrm{MJ}$ compared to $516 \mathrm{MJ}$ for partial electronic auditing. However energy consumption by the partial electronic system remained lower for the auditing of the companies $1000 \mathrm{~km}$ away.

\section{Figure 9: Energy consumption when local distance travelled is $20 \mathrm{~km}$ per day}

The use of a car for local auditing was found to have advantages for distances of $17 \mathrm{~km}$ per day and below. This doubled when the fuel efficiency was doubled from 10 to $20 \mathrm{~km} /$ litre. The use of a more fuel-efficient car did not change the advantage of electronic systems over traditional systems generally though. However it made the use of a car better than an airplane. Using a hybrid car with a fuel efficiency of $25 \mathrm{~km} /$ litre reduced the traditional system energy consumption of a car over a distance of $1000 \mathrm{~km}$ to $1729 \mathrm{MJ}$ lower than $3785 \mathrm{MJ}$ for the airplane, reversing the previous situation when the use of the car consumed more energy in total.

When the number of audit days is the same for partly electronic systems, all the transport modes and scenarios show that partly electronic audit systems use more energy than traditional ones. However partly electronic auditing system remained better than traditional system when the partly electronic auditing period was increased to 4 days. Also taking the worst-case scenario of the dedicated use of a $10000 \mathrm{~W}$ mainframe computer server for auditing resulted in the use of a train in a traditional auditing system being better than the partly electronic system. This demonstrates the robustness of the model. Furthermore, a total of 37 variables were tested for sensitivity and most of them did not affect the dominance of the partly electronic system over the traditional one.

\subsection{General discussion}

The models used have given interesting results that contribute to knowledge in this area. Naturally there are some errors to do with the assumptions made and the use of data from external sources. The accuracy of the results thus depends on the validity of the models and assumptions used. The results have to be used with care, because one of the main assumptions is that use of electronic methods results in the number of audit days being reduced from 5 to 3 . The advantages of electronic systems are almost completely wiped out when the number of audit days is the same for the two systems. The results 
also show that information and communication technology (ICT) systems do not automatically offer energy and environmental impact reductions when they are used. There are conditions under which they do so and these have been outlined in the last section. The use of rail transport for long distances and using the nearest station and hotel to the audited company offers opportunities for energy saving and environmental impact reduction, when auditing companies. These benefits can be increased substantially by contracting auditors that are located closest to the facility that is being audited. This reduces transportation effects, which dominate energy consumption in this case.

The sensitivity behaviour of the model demonstrates that it is robust to changes in the variables used. The sensitive variables have been discussed already and even then only affect local auditing for a limited amount of the distance travelled per day. The main problem in this study was in getting information from the automobile companies on the location of their auditors and the distance from the audited facilities. However the few companies that responded had inadequate data and showed that most of the auditors were stationed in Tokyo. This lack of data is adequately compensated for by the broad sensitivity analysis that has been done, covering all the 37 variables. The results are therefore not only appropriate for the Japanese automotive industry only, but can also be applied in other organizations and companies in countries like South Africa. Getting exact data from the 97 facilities certified to ISO 14001 in the Japanese automotive industry, which does exist for most of the variables, will not change the findings and results of this study, particularly the overall conclusions that are derived. It also corroborates results of similar studies (Arnfalk, 2000).

Studies of this nature at a micro-level are very important in trying to understand the total system. A company-wide usage of videoconferencing facilities improves the benefits of the technology since its life cycle energy impacts are the shared. The study highlights the need to consider transportation activities in ISO 14001 certified companies. If travel increases without control, the intended benefits from certification can be reversed. The tendency to consider travel as a fringe benefit should change. The analysis that has been carried out also ignores issues like personal and social contact, dining and wining after meetings and the desire for people to see new places. The other problem is that some people feel uncomfortable using videoconferencing since they feel like they are taking part in an artificial movie, affecting their performance, hence compromising the quality of the audit. Some studies suggest that the output of videoconference meetings is $60 \%$ that of real meetings. (Arnfalk, 2000) On the other hand some employees like the frequent flyer points, tax-free goods, making new business contact during travel, allowances and the status of being important customers of the transporting companies. These factors would need to be taken into account in future research.

Technical problems can also be frustrating like meeting 
interruptions, picture problems, sound problems and connection problems. This study has assumed that these problems do not arise and the videoconferencing system works at the set times, when it is needed. These issues would need to be addressed. Also company policy changes and new laws, regulations might be needed to substitute travel through videoconferencing. Publication of the environmental impacts of travel within a company internally and externally can help to drive the message home. In addition teleconferencing should be made easier to use through constant acquisition of the best technology and ensuring accessibility, convenience and easy of use.

\section{Conclusion}

The current pace of globalization cannot continue using old management models that promote more international face-to-face meetings and travel. Many industry leaders spend more than 6 weeks a year at $10,000 \mathrm{~m}$ flying from one place to another and time away from home is often doubling every 24 months. (Dixon, 2003) This affects families and videoconferencing is one way to avoid this developing social problem. This study has modelled and compared the energy implications of ICT use in auditing systems against the purely traditional systems that are manual and do not use the Internet and videoconferencing. The main findings and conclusions of the study are as follows:

- The use of partly electronic auditing systems is more energyefficient when compared to traditional systems for all situations except when the local distance travelled per day is $75 \mathrm{~km}$ or less per day using a train and $17 \mathrm{~km}$ or less per day, when a car is used. The car distance boundary can double when a more fuel-efficient car is used. This suggests that the use of an electronic auditing system may not be justified for companies within a $75 \mathrm{~km}$ a day boundary, which are accessible by train and car.

- Rail travel is the best mode for all ranges of distances, consuming less than $25 \%$ of the energy used by a car for local travel.

- The use of a car with a fuel performance of $11 \mathrm{~km} /$ litre or less results in more transportation energy consumption compared to the use of an airplane for long distances. The use of a more fuel-efficient car can result in better performance than airplane travel. A Toyota gasoline vehicle in the same class as the Toyota Estima hybrid model has a fuel efficiency of $10.2 \mathrm{~km} /$ litre, while the hybrid version at fuelefficiency of $18 \mathrm{~km} /$ litre.

- Travel dominates energy consumption, rendering paper life cycle, printing and energy use in office buildings comparatively insignificant. This dominance by travel suggests strongly the need to use contract auditors based in the same area as the audited company whenever feasible. For example auditors $1000 \mathrm{~km}$ away from 
audited site consume more than two and a half times the energy consumed by local auditors for the variables set in this study.

The study has brought forward more information on how ICT can contribute to reducing energy consumption and hence related environmental impacts. The study could be extended to cover the possible use of buses and ships for transporting the auditors. However the results of using the bus can be inferred form indices in Table 4 which show that on the average buses in Japan, consume $0.61 \mathrm{MJ}$ per passenger-kilometre, somewhere between the figure for the train and for the car. More analysis and data collection would be necessary for ship transportation. The mode is slow, less flexible and not always applicable.

It has also been indicated that distance education using ICT is a variant of remote conferencing and offers similar benefits through travel substitution. Education and training of stakeholders and employees is one of the requirements of ISO14001 and this can be done effectively through electronic media. E-mails and communication can be enabled between instructors and learners through personal computers, videoconferences and teleconferences in virtual seminars. (GeSI UNEP, 2002) These and other areas of study are candidates for further studies that can use inferences and draw parallels from this study. The results in this microanalysis not only contribute to decisions in auditing, but also provide micro-level data, which can be used to analyze the overall energy and environmental impacts of ICT use in environmental management and how it can be used to improve that performance. These results have applications and implications that extend to organisations in Southern Africa, beyond the initially targeted Japanese automotive industry.

\section{Reference}

Aebischer Bernard, Frishknecht Rolf, Genoud Christophe, Huser Alois, Varone Frederic, 2002, Energy

Efficiency Indicator for High Electric-Load Buildings. The Case of Data Centres

Arnfalk Peter, 2000, The Use of Telework and Teleconferencing in Travel Reduction, Paper for the Eco

Efficiency 2000 Conference, June 2000, Malmo

Baxter CVG, Case Study Summary: The Economical and Ecological Implications of Solid Waste

Reduction Program. http://www.wastereduction.org/Baxter/ Bax5.htm

Brother Europe, HL-1070 laser printer Specifications, 
http://www.brother.com/eu-printer/info/hl1000/br_1070.html

Callaghan Paul W., 1996, Integrated Environmental Management Handbook, John Willey \& Sons

Cohen N., 2001, The Environmental Impacts of E. Commerce, Proceedings of Sustainability in the

Information Society, $15^{\text {th }}$ International Symposium on Informatics for Environmental Protection, Zurich 10-12 October 2001, pages 41-52.

Daihatsu, 2002, Daihatsu Motor Co., LTD. 2002 Environmental Report, 27 September, 2002, Daihatsu

Motor Co., Ltd., Osaka

DEQ, 1999, Oklahoma Department of Environmental quality: Fact Sheet,

Dixon Patrick, 2003, Multimedia lectures by videoconference,

http://www.globalchange.com/videoconfdemo.html last accessed on February 25, 2008

Earthsystems, 2001, What is recycled paper? http://earthsystems.org/ education/recyclepaper.html

EETD Newsletter, 2003, Hotel Survey Illuminates Energy Savings,

http://eetd.lbl.gov/newsletter/n16/hotels.html

EPA, 2004, Annual energy consumption of a typical office configuration,

http://www.epa.gov/oaintrnt/content/energy/text.htm

EPA, 2001, Inventory of US Greenhouse Gas Emissions and Sinks: 1990-1999, April 2001, United States

Environmental Protection Agency, Washington, USA

EPSON EPL-6100L, 16-ppm monochrome laser printer, http:// www.epson.com.sg/6100Lspec.pdf

FSEC, 2003, Typical Savings in Caribbean Hotels, http:// www.fsec.ucf.edu/ed/internat/typ_savings.htm

GeSI UNEP, 2002, Information and Communications Technology: Industry as a partner for sustainable

development, UNEP Division of Technology, Industry and Economics, Paris, France

Herring Horace, 2001, The Rebound Effect, Sustainability Consumption and Electronic Appliances,

Proceedings of Sustainability in the Information Society, $15^{\text {th }}$ International Symposium on Informatics for Environmental 
Protection, Zurich 10-12 October 2001, pages 870-876

Honda, 2002, Honda Environmental Annual Report 2002, August 2002 Honda Motor Co., Ltd., Tokyo

ISO 14001, 1996, International Standard ISO 14001, Environmental management systems-Specifications with

guidance for use, Technical Committee 207, Geneva: International Standards Organization

Isuzu Motors, 2002, Isuzu Environmental Report, November 2002, Isuzu Motors Limited Public Relations

Department, Tokyo

JAL, 2001, Japan Airlines and Japan Air System 2001 Annual Environmental Report,

http://www.jal.co.jp/en/environment/

JR East, 2002, East Japan Railway Company Social and Environmental Report, September, 2002

Matthews Scott H., Hendrickson Chris T., Chong Hu Min and Loh Woon Sien, 2002, Energy Impacts of

Wired and Wireless Networks, Presented at the IEEE International Symposium on Electronics and the Environment, May 6-9, 2002, San Francisco, CA, USA pp 44-48

Mazda, 2002, 2002 Environmental Report, Mazda Motor Corporation, Hiroshima, Japan

Miyamoto Shigeyuki, Harada Hiroo, Fujimoto Jun, Environmental Impact Assessment for Various

Information Technology Systems and Classification by Their Environmental Aspects, 2001 IEEE pages 785-790

Mitsubishi, 2002, Environmental Sustainability Report 2002: Mitsubishi Motors, Mitsubishi Motors

Corporation, Tokyo

NEC, 2001, Annual Environmental Report April 200 - March 2001, A Look into the Next Chapter of

Ecology and Technology

Nissan, 2002, Environmental and Social Report: Year Ended March 31, 2002, Nissan Motor Co., Ltd

Environmental Management Committee, Tokyo

PictureTel Concorde 4500, 2004, PictureTel Concorde 2000 System http: / / www.engr.wisc.edu / services / ems / services / pdfs / GSconcorde4500.pdf

PictureTel Venue 2000, 2004, PictreTel Venue 2000 System Model 
30, http://www.unilim.fr/sci/visio/venue30s.htm

Roth Kurt, Goldstein Fred and Kleinman Jonathan, 2002, Energy Consumption by Commercial Office and

Telecommunications Equipment in the US, Presented at the IEECB Conference, 29 May 2002, Nice, France.

Statistical Handbook of Japan, 2002, http://www.stat.go.jp/english/ data/handbook/c08cont.htm

SwiftSite II, 2004, Portable Videoconferencing System http:// www.estelsystems.bg/datasheets/swift2.pdf

Subaru - Fuji, 2002, 2002 Environmental Report: Fuji Heavy Industries Limited, September 2002 Fuji

Heavy Industries Ltd., Tokyo

Suzuki, 2001, 2001 Suzuki Environmental Report, March 2002, Suzuki Motor Corporation Environmental

Planning Department, Takatsuka, Hamamatsu, Japan

Suzuki, 2002, 2002 Suzuki Environmental Report, September 2002, Suzuki Motor Corporation

Environmental Planning Department, Takatsuka, Hamamatsu, Japan

Toyota, 2001, Toyota Motor Corporation: Environmental Report 2001, August 2001, Toyota Motor

Corporation Environmental Affairs division, Tokyo

Toyota, 2002, Toyota Motor Corporation: Environmental Report 2002, August 2002, Toyota Motor

Corporation Environmental Affairs division, Tokyo

West Mike and Elliot Larry, Energy management Programs that Increased Hotel and Motel Profits,

http: / / edis.ifas.ufl.edu/BODY_EH398

Williams Eric and Tagami Takashi, 2002, Energy use in sales and distribution via B2C E-commerce and

conventional retail: a case study of the Japanese book sector. Journal of Industrial Ecology 6(2)

Young Steven Scott, 1994, Environmental Auditing, Pollution Engineering, The magazine of

Environmental Control, Cahners Publishing Company, USA 